\title{
Review Article \\ Biodegradable Magnesium Alloys Developed as Bone Repair Materials: A Review
}

\author{
Chen Liu, ${ }^{1,2}$ Zheng Ren, ${ }^{2}$ Yongdong Xu, ${ }^{2}$ Song Pang, ${ }^{2}$ Xinbing Zhao, ${ }^{1}$ and Ying Zhao $\mathbb{D}^{3}$ \\ ${ }^{1}$ Department of Materials Science and Engineering, Zhejiang University, Hangzhou, China \\ ${ }^{2}$ Ningbo Branch of China Academy of Ordnance Science, Ningbo, China \\ ${ }^{3}$ Shenzhen Institutes of Advanced Technology, Chinese Academy of Sciences, Shenzhen, China \\ Correspondence should be addressed to Ying Zhao; ying.zhao@siat.ac.cn
}

Received 28 July 2017; Revised 3 November 2017; Accepted 5 February 2018; Published 13 March 2018

Academic Editor: Daniele Passeri

Copyright (C) 2018 Chen Liu et al. This is an open access article distributed under the Creative Commons Attribution License, which permits unrestricted use, distribution, and reproduction in any medium, provided the original work is properly cited.

\begin{abstract}
Bone repair materials are rapidly becoming a hot topic in the field of biomedical materials due to being an important means of repairing human bony deficiencies and replacing hard tissue. Magnesium $(\mathrm{Mg})$ alloys are potentially biocompatible, osteoconductive, and biodegradable metallic materials that can be used in bone repair due to their in situ degradation in the body, mechanical properties similar to those of bones, and ability to positively stimulate the formation of new bones. However, rapid degradation of these materials in physiological environments may lead to gas cavities, hemolysis, and osteolysis and thus, hinder their clinical orthopedic applications. This paper reviews recent work on the use of $\mathrm{Mg}$ alloy implants in bone repair. Research to date on alloy design, surface modification, and biological performance of $\mathrm{Mg}$ alloys is comprehensively summarized. Future challenges for and developments in biomedical $\mathrm{Mg}$ alloys for use in bone repair are also discussed.
\end{abstract}

\section{Introduction}

As the largest dynamic biological tissue in the body, bones are composed of inorganic minerals and metabolically active cells surrounded by a large volume of extracellular matrix, and they form a rigid framework that has an irreplaceable role in maintaining life activities, including supporting the body and protecting visceral organs $[1,2]$. Surgical treatment of bone injuries has become common, where there are millions of bone injury patients in emergency departments worldwide each year due to involvement in vigorous athletic activities, social instability, traffic accidents, and prolonged human lifespan [3-5]. Bone defects, mainly induced by traumatic avulsions, sequelae of infection-induced bony sequestration, congenital malformations, or neoplastic resections, confront us with an extreme challenge for reconstructive surgery. The need to induce bone regeneration to repair structural bone deficiencies has inspired research on and development of a vast number of bone repair materials $[2,6]$.

Bone repair is a physiological process influenced by a variety of biomechanical, biochemical, cellular, hormonal, and pathological factors. Continuous bone deposition, resorption, and remodeling and sufficient blood supply promote bone repair [7]. Based on the basic principles of bone tissue healing, different bone repair materials have been developed. For a long time, autograft bones have been considered the gold standard of bone repair materials when replacing damaged or lost bones because they have all the characteristics necessary to stimulate new bone growth of osteoconductivity, osteogenicity, and osteoinductivity. However, resources for these autografts are scarce and secondary surgeries increase the pain experienced by patients. Furthermore, donor-site complications can occur, clinical benefits are not guaranteed, and there is a high rate of associated complications $[4,8,9]$. A large number of alternative bone repair materials have been increasingly used to replace autograft bones and are commercially available as bone substitutes. The most commonly used products are composed of calcium (Ca) phosphate ceramics, Ca sulfate, bioactive glass, natural materials, and biological/synthetic composites [10-15]. However, the clinical performance of these materials is unsatisfactory. For example, some have poor mechanical 
properties and display limited osteoinduction in the clinic $[16,17]$. Metallic materials are another alternative for use in the repair or replacement of diseased or damaged bone tissue. Metallic materials currently widely used in orthopedics include stainless steel and titanium alloys because they are mechanically strong and resistant to fracture [18-21]. However, there is a potential for the release of metallic ions and/or particles through corrosion and/or wear that trigger inflammatory responses that can reduce biocompatibility and lead to tissue loss. Furthermore, the elastic moduli and tensile strength of metals and bone are significantly different, which can cause stress shielding and result in weakening of surrounding bone. These inert implants also often need to be removed via invasive secondary surgeries once the bone fracture has completely healed. To minimize trauma to the patients and decrease medical costs, biodegradable implants could be used to replace traditional metal implants and remove the need for secondary surgeries [22-26].

Magnesium (Mg) alloys have a reputation for being revolutionary biodegradable metal materials in orthopedic applications due to their good biocompatibility, biodegradability, and acceptable mechanical properties [27-30]. The fourth most plentiful cation in the human body, $\mathrm{Mg}$ is an element essential in many metabolic processes and is primarily stored in bone tissue. $\mathrm{Mg}$ is taken into the body daily in substantial amounts, stimulates the growth of bone cells, and accelerates the healing of bone tissue. $\mathrm{Mg}$ alloys are degraded in vivo due to the presence of $\mathrm{Cl}^{-}$in the physiological environment, thereby eliminating the need for secondary surgeries to remove the implant. $\mathrm{Mg}^{2+}$, a corrosion product of $\mathrm{Mg}$ alloy implants, does not cause unexpected complications because excessive $\mathrm{Mg}$ cations are easily eliminated in the urine [3134]. Moreover, $\mathrm{Mg}$ alloys have mechanical properties similar to those of bone. $\mathrm{Mg}$ alloys are lightweight with densities $\left(1.7-1.9 \mathrm{~g} / \mathrm{cm}^{3}\right)$ very similar to those of human cortical bone $\left(1.75 \mathrm{~g} / \mathrm{cm}^{3}\right)$, unlike titanium alloys (Ti-6Al-4V $4.47 \mathrm{~g} / \mathrm{cm}^{3}$ ) and stainless steel (about $7.8 \mathrm{~g} / \mathrm{cm}^{3}$ ). The elastic modulus of $\mathrm{Mg}$ alloys, about $45 \mathrm{GPa}$, is relatively close to that of natural bone, 3-20 GPa, compared to the elastic moduli of titanium alloys and stainless steel (110 and $200 \mathrm{GPa}$, resp.). Therefore, the stress shielding from the notable mechanical mismatch between natural bone and metal implants should be mitigated [35-37]. Therefore, $\mathrm{Mg}$ alloys are expected to become biocompatible, biodegradable, lightweight, and loadbearing orthopedic implants [22, 38-40].

While research on $\mathrm{Mg}$ alloys as bone implants has led to significant progress over the past 20 years, rapid degradation of these materials inside the human body is still a major obstacle hampering their use in the clinic. As biodegradable materials, it is important that the rate of implant degradation matches the rate of healing of the bone tissue, which generally consists of an early inflammatory stage lasting from 3 to 7 days, a reparative stage that leads to a strong healing union lasting about 3-4 months, and then a remodeling phase that can last months to years [41-43]. Therefore, it is necessary for the implant to remain stable for at least 12 weeks [22]. However, the currently available Mg alloys degrade too quickly to hold well during implantation. This fast degradation results in the formation of hydrogen gas cavities, rapid loss of mechanical integrity of the implants, and adverse host tissue reactions, such as local swelling and significant pain within the first week after surgery [44-46].

There have been a number of recent opportunities and challenges in the development of $\mathrm{Mg}$ alloys for use in bone repair. Therefore, it is necessary to summarize the findings of the researchers in this field. Compared to recently published reviews [27, 47-53], this paper is more targeted and specifically discusses biodegradable $\mathrm{Mg}$ alloys to be used in bone repair. We review the alloying design, surface modifications, and the in vitro and in vivo biological performance of $\mathrm{Mg}$ in bone repair. Novel insights that have been used to improve the compatibility and reliability of biomedical $\mathrm{Mg}$ alloys in the bone reconstruction field are also discussed.

\section{Alloying Design of Magnesium Alloys}

Adequate strength, ductility, fatigue resistance, and biocorrosion resistance are important characteristics for biodegradable implants to be used in orthopedic applications. Because adding alloying elements can improve mechanical properties and decrease the corrosion rate of $\mathrm{Mg}$ by modifying the structure and phase distribution, several Mg alloys have been designed to meet the requirements of bone repair implant materials $[30,32,60]$.

2.1. Alloying Elements. Careful selection of alloying elements is the first step in designing $\mathrm{Mg}$ alloys. To strengthen $\mathrm{Mg}$ based materials, adding elements such as $\mathrm{Al}, \mathrm{Zn}, \mathrm{Ca}, \mathrm{Ag}, \mathrm{Ce}$, and Th can generate different microstructures and improve the mechanical properties of the resulting $\mathrm{Mg}$ alloy [71-74]. In terms of corrosion, alloying elements that have electrochemical potentials similar to that of $\mathrm{Mg}(-2.37 \mathrm{~V})$, such as $\mathrm{Y}$ $(-2.37 \mathrm{~V}), \mathrm{Nd}(-2.43 \mathrm{~V})$, and $\mathrm{Ce}(-2.48 \mathrm{~V})$, and have relatively high solid solubility in $\mathrm{Mg}$, such as Sc (25.9 wt.\% limit), Gd (23.5 wt.\% limit), and Dy (25.3 wt.\% limit), can enhance the corrosion resistance by reducing internal galvanic corrosion in physiological environments [37, 75, 76]. Biocompatibility also needs to be considered. Previous reports have shown that biological nutrients (e.g., $\mathrm{Ca}, \mathrm{Sr}, \mathrm{Zn}, \mathrm{Si}$, and $\mathrm{Mn}$ ) and trace nontoxic elements (e.g., $\mathrm{Zr}, \mathrm{Nd}$, and $\mathrm{Y}$ ) added either independently or together to the $\mathrm{Mg}$ matrix do not cause detrimental local tissue responses and can be easily absorbed by surrounding tissues $[29,30,35,77-80]$. With the development of biodegradable Mg alloys, researchers have started trying to endow $\mathrm{Mg}$ alloys with new biomedical functions through alloying. $\mathrm{Ca}, \mathrm{Sr}, \mathrm{Ag}$, and $\mathrm{Cu}$ as biofunctional trace metallic elements have been confirmed to promote bone cell activation and stimulate new bone formation. In addition to promoting osteogenesis, these elements also inhibit bacterial infection after implantation, thereby effectively decreasing morbidity and mortality, by making the environment alkaline and releasing antimicrobial metallic ions [81-86].

2.2. Alloy Systems. Due to having a combination of good mechanical properties and corrosion resistance, some commercial Mg alloy systems have been selected as biodegradable $\mathrm{Mg}$ alloys at an early stage. Commercial $\mathrm{Mg}$ alloys used in biological research include the AZ (Mg-Al-Zn), WE (Mg-RE$\mathrm{Zr})$, and $\mathrm{ZK}(\mathrm{Mg}-\mathrm{Zn}-\mathrm{Zr})$ series alloys. 
AZ series alloys, particularly AZ31 (Mg-3Al-1Zn) and AZ91 (Mg-9Al-1Zn) alloys, have been extensively studied both in vitro and in vivo in recent years [46, 87-89]. It has been reported that AZ31 and AZ91 alloys release hydrogen upon degradation in physiological environments, leading to a significant increase in both $\mathrm{pH}$ and $\mathrm{Mg}$ ion concentration [90]. In Hank's solution, the AZ31 alloy degrades more slowly than the AZ91 alloy, but there is no significant difference in vivo [91, 92]. Short-term in vivo studies of AZ31 and AZ91 alloys have also revealed that a biocompatible Ca phosphate protective film layer covers their surfaces and increases the formation of new bone mass around the implants $[92,93]$.

WE series alloys have good biocorrosion resistance because they form a rare-earth (RE) oxide film in aqueous environments. It has been reported that WE54 $(1.58 \mathrm{Nd}$, $4.85 \mathrm{Y}, 0.28 \mathrm{Zr}, 0.08 \mathrm{Ce}, 0.13 \mathrm{Gd}, 0.16 \mathrm{Er}, 0.13 \mathrm{Yb}$, and balanced $\mathrm{Mg}$ in wt.\%) has marginally higher resistance to degradation in vitro than pure $\mathrm{Mg}$ and heat treatment impacts its degradation [94]. Witte et al. analyzed the in vivo degradation of four different $\mathrm{Mg}$ alloys and confirmed that WE43 (4.16 Y, 3.80 RE, 0.36 Zr, 0.20 Zn, and 0.13 Mn, all in wt.\%) has good biocompatibility [93]. However, an increase in $\mathrm{Al}$ ion concentration in the brain is associated with the occurrence of Alzheimer's disease and severe hepatotoxicity has occurred after the administration of RE elements, such as $\mathrm{Y}, \mathrm{Ce}$, and $\operatorname{Pr}[6]$.

Recently, ZK series alloys, especially ZK40 (Mg-4Zn$0.5 \mathrm{Zr}$ ) and ZK60 (Mg-6Zn-0.5Zr), have attracted the attention of researchers because of the good biocompatibility of the component elements [95-97]. A daily intake of $11 \mathrm{mg} \mathrm{Zn}$ and $50 \mu \mathrm{g} \mathrm{Zr}$ is permissible, so $\mathrm{Mg}-\mathrm{Zn}-\mathrm{Zr}$ alloys are more attractive than $\mathrm{Mg}-\mathrm{Al}-\mathrm{Zn}$ and $\mathrm{Mg}-\mathrm{RE}-\mathrm{Zr}$ alloys in terms of element biocompatibility and biosafety and are candidate biodegradable metals for use in bone repair devices [25]. However, the extremely high rates of degradation of $\mathrm{Mg}-\mathrm{Zn}$ $\mathrm{Zr}$ alloys are alarming and restrict their future development.

In addition to the above commercial $\mathrm{Mg}$ alloy systems, new $\mathrm{Mg}$ alloys have also been developed for use in orthopedic applications, including $\mathrm{Mg}$-Ca, $\mathrm{Mg}-\mathrm{Sr}, \mathrm{Mg}-\mathrm{Zn}$, and $\mathrm{Mg}$ - $\mathrm{RE}$ alloy systems.

$\mathrm{Ca}$, acting as a grain-refining agent in $\mathrm{Mg}$ alloys, can stabilize grain size at levels up to $0.5 \%$ of the Ca content and cause slight decreases with further addition [98]. As a major component of human bone, $\mathrm{Ca}$ is essential for bone cell signaling and beneficial to bone healing. It has been reported that $\mathrm{Mg}-1 \mathrm{Ca}$ alloy does not induce cytotoxicity and osteoblasts and osteocytes are highly active around $\mathrm{Mg}-1 \mathrm{Ca}$ alloy pins implanted in rabbit femoral shafts, thus demonstrating good biocompatibility and bioactivity [84].

Strontium (Sr) and Ca belong to the same family and have similar physical and chemical properties and biological functions. Brar et al. studied Mg- $x$ wt. $\% \operatorname{Sr}(x=0.5,1.0$, and $1.5 \mathrm{wt} . \%)$ alloys and found that the $\mathrm{Mg}-0.5 \mathrm{Sr}$ alloy degraded the slowest [35]. Zhao et al. and $\mathrm{Gu}$ et al., respectively, reported that the as-extruded $\mathrm{Mg}-0.5 \mathrm{Sr}$ and as-rolled $\mathrm{Mg}-2 \mathrm{Sr}$ alloys had the best combination of corrosion resistance, high strength, and in vivo biocompatibility [86, 99].

Zinc $(\mathrm{Zn})$ is one of the most abundant essential nutrients in the human body and is safe for use in biomedical
TABLE 1: Common second phases of select biodegradable Mg alloys.

\begin{tabular}{lc}
\hline $\begin{array}{l}\text { Biodegradable magnesium } \\
\text { alloys }\end{array}$ & $\begin{array}{c}\text { The second phases in magnesium } \\
\text { matrix }\end{array}$ \\
\hline AZ31B [61], AZ61D [62] & $\mathrm{Mg}_{17} \mathrm{Al}_{12}$ \\
AZ91D [63, 64] & $\mathrm{Mg}_{17} \mathrm{Al}_{12}, \mathrm{Al}_{8} \mathrm{Mn}_{5}$ \\
$\mathrm{Mg}-\mathrm{Ca}[65]$ & $\mathrm{Mg}_{2} \mathrm{Ca}$ \\
Mg-Sr [4, 65] & $\mathrm{Mg}_{17} \mathrm{Sr}_{2}, \mathrm{Mg}_{2} \mathrm{Sr}$ \\
Mg-Zn [66] & $\mathrm{MgZn}_{2}$ \\
Mg-Zn-Ca [67] & $\mathrm{Mg}_{2} \mathrm{Zn}_{3}$ \\
Mg-Si [66] & $\mathrm{Mg}_{2} \mathrm{Si}$ \\
$\mathrm{Mg}-\mathrm{Al}-\mathrm{Si}[68]$ & $\mathrm{Mg}_{2} \mathrm{Si}$ \\
WE43 [69] & $\mathrm{Mg}_{24} \mathrm{Y}_{5}, \mathrm{Mg}_{41} \mathrm{Nd}_{5}, \mathrm{Mg}_{12} \mathrm{Nd}$ \\
ZK60 [70] & $\mathrm{MgZn}_{\mathrm{MgZn}}$ \\
\hline
\end{tabular}

applications [100]. The rate of $\mathrm{Mg}$ corrosion can be reduced by increasing the mass fraction of $\mathrm{Zn}$ mixed with $\mathrm{Mg}$, thus strengthening the mechanical properties of $\mathrm{Mg}$ through solid solution hardening [101]. Cai et al. reported that a $\mathrm{Zn}$ content of up to $5 \mathrm{wt} . \%$ in $\mathrm{Mg}$ - $\mathrm{Zn}$ binary alloys exhibits grain boundary, solid solution, and secondary phase strengthening, resulting in improved resistance to corrosion and mechanical properties [102]. Mg-6Zn alloy has good biocompatibility in vitro based on hemolysis and MC3T3-E1 cell adhesion assays [103].

Because Mg-RE alloys have good mechanical properties and corrosion resistance, new Mg-RE alloys, such as MgY, Mg-Nd, Mg-Gd, Mg-Ce, and Mg-Ld, have been studied. Among these, Mg-Nd alloy has a much slower corrosion rate than the other alloys [74]. Mg-Y alloy was prepared using a zone solidification method and improved corrosion resistance and mechanical properties [104]. Mg-Y-Zn alloy contains an interesting combination of preferred microstructural, mechanical, electrochemical, and biological properties, making it very promising for use as a biodegradable implant material [105].

2.3. Alloy Microstructures. Alloying elements in Mg alloys may exist in the form of second-phase particles and precipitate in grains or grain boundaries, substantially enhancing mechanical properties through second-phase strengthening.

Figure 1 presents the typical morphologies of second phases for Mg alloys and Table 1 presents the second phases of biodegradable $\mathrm{Mg}$ alloys. Compared to $\mathrm{Mg}$ matrix, second phases have higher potentials and may facilitate corrosion, leaching into the physiological environment accompanied with the degradation of the matrix. Kannan investigated the degradability of $\mathrm{Mg}_{17} \mathrm{Al}_{12}$ phase in simulated body fluid (SBF) using electrochemical measurements and found that the degradation rate of $\mathrm{Mg}_{17} \mathrm{Al}_{12}$ was lower than that of bare $\mathrm{Mg}$. Our previous study demonstrated that pitting corrosion occurs with crackings for $\mathrm{Mg}_{17} \mathrm{Al}_{12}$ phase in Hank's solution and degrades much slower than AZ31 alloy and pure $\mathrm{Mg}$ [106].

When assessing $\mathrm{Mg}$ alloy implants for use in bone repair, the stability of second phases and $\mathrm{Mg}$ matrix under different 


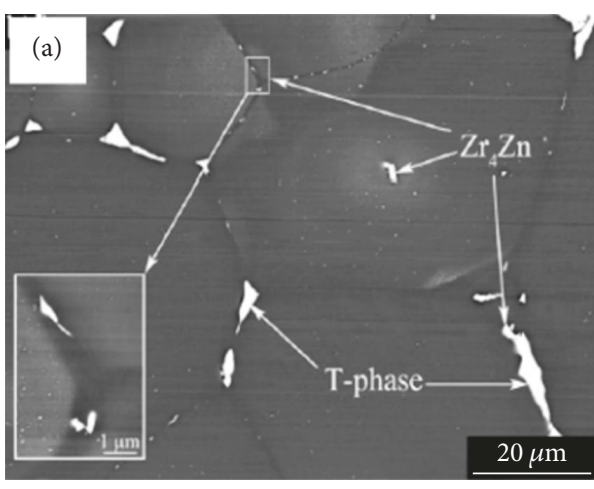

(a)

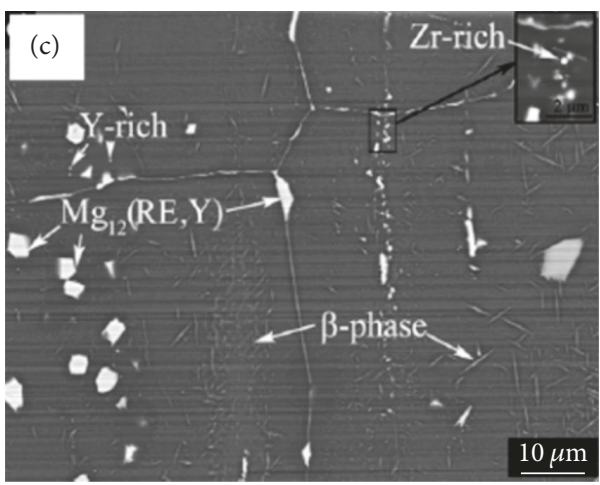

(c)

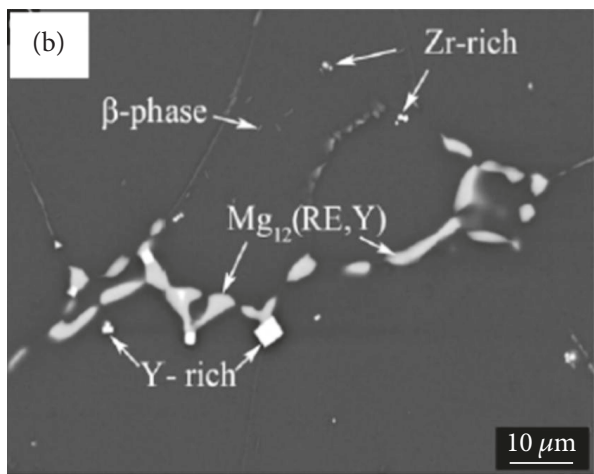

(b)

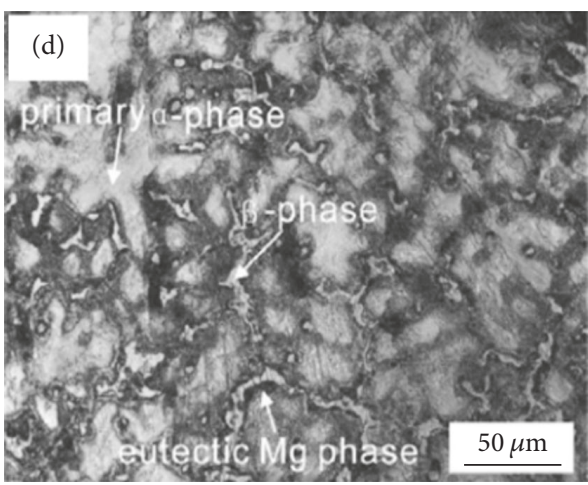

(d)

FIGURE 1: Typical morphologies of second phases in (a) as-cast ZE41, (b) as-cast WE43, (c) as-forged WE43 [54], and (d) AZ91D alloys [55].

conditions may have significantly influenced degradation and biological responses to the implant in the body. Yang et al. theoretically investigated the thermodynamic stability of four conventional second phases for $\mathrm{Mg}-\mathrm{Zn}-\mathrm{Zr}, \mathrm{Mg}-$ $\mathrm{Ca}, \mathrm{Mg}-\mathrm{Sr}$, and $\mathrm{Mg}-\mathrm{Al}-\mathrm{Zn}$ alloys, as well as $\mathrm{Mg}$ matrix in bioabsorbable $\mathrm{Mg}$ alloys, via the $\mathrm{Dmol}^{3}$ calculation method. The second phases had higher phase stability than Mg matrix, but the phase stability was quite different for different types of second phases and second-phase- $4 \mathrm{H}_{2} \mathrm{O}$ systems [71]. In order to evaluate the effect of second phases on the biological safety of biodegradable $\mathrm{Mg}$ alloy implants, $\mathrm{Mg}_{17} \mathrm{Al}_{12}$ second phase from $\mathrm{Mg}-\mathrm{Al}-\mathrm{Zn}$ alloys was investigated for in vitro biocompatibility and phagocytosis by macrophages. $\mathrm{Mg}_{17} \mathrm{Al}_{12}$ second phase did not induce hemolysis and had excellent cytocompatibility. $\mathrm{Mg}_{17} \mathrm{Al}_{12}$ particles are processed in endolysosomal compartments and lysosomes play a major role in digesting $\mathrm{Mg}_{17} \mathrm{Al}_{12}$ particles [107].

However, not all the alloying elements in $\mathrm{Mg}$ alloys form second-phase particles. As mentioned above, some alloy elements have relatively high solid solubility in $\mathrm{Mg}$, such as Y (12 wt.\% limit), Sc (25.9 wt.\% limit), Gd (23.5 wt.\% limit), and Dy (25.3 wt.\% limit), and can exist in the form of solid solutions, thus achieving solid solution strengthening. In the solution, the original crystal structure of magnesium remains unchanged, but a lattice distortion is produced and thus the motion of dislocations becomes impeded, which leads to the enhancement of strength of $\mathrm{Mg}$. Gao et al. explored the effects of solid solutions on the mechanical behavior of binary Mg-Y single-phase alloys. They found enhanced hardness as the $\mathrm{Y}$ content increased at room temperature because of large differences in the atomic radii of $\mathrm{Y}$ and $\mathrm{Mg}$ and a relatively wide range of solubilities [108]. Moreover, solid solution alloying also potentially affects degradation of $\mathrm{Mg}$ alloys by improving corrosion resistance by reducing internal galvanic corrosion between the second phase and Mg matrix. Zhang et al. studied the effect of solid solution treatment on the corrosion and electrochemical behaviors of Mg-15Y alloy and found that solution treatment decreased the extent of galvanic corrosion due to the dissolution of $\mathrm{Mg}_{24} \mathrm{Y}_{5}$ second phase into the matrix [109]. Therefore, solid solution might be a feasible alternative for generating a single-phase $\mathrm{Mg}$ alloy and can help improve the corrosion resistance of $\mathrm{Mg}$ alloys in orthopedic applications.

2.4. Impurities in Magnesium Alloys. During casting and refining, magnesium always introduces superfluous amounts of impurity elements. Impurity elements in $\mathrm{Mg}$ alloys usually include iron $(\mathrm{Fe})$, nickel $(\mathrm{Ni})$, and copper $(\mathrm{Cu})[66,110]$. These elements can significantly accelerate $\mathrm{Mg}$ corrosion when their concentrations exceed the limits of tolerance [111-113]. Standards for $\mathrm{Mg}$ impurity elements are 35-50 ppm for Fe, 20-50 ppm for Ni, and 100-300 ppm for $\mathrm{Cu}$ (wt.\%). Below the tolerance limits, no impurity particles are formed and, thus, no electrochemically active cathodic sites exist to accelerate 


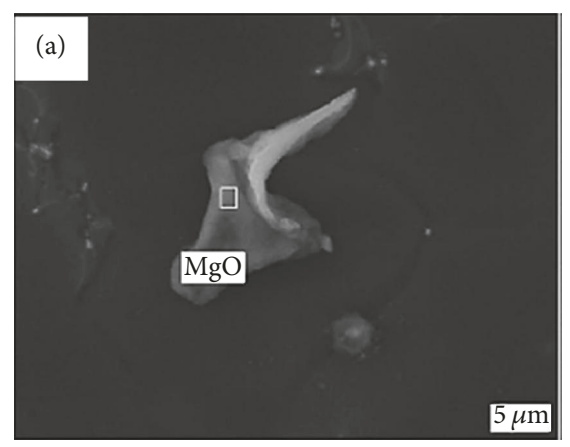

(a)

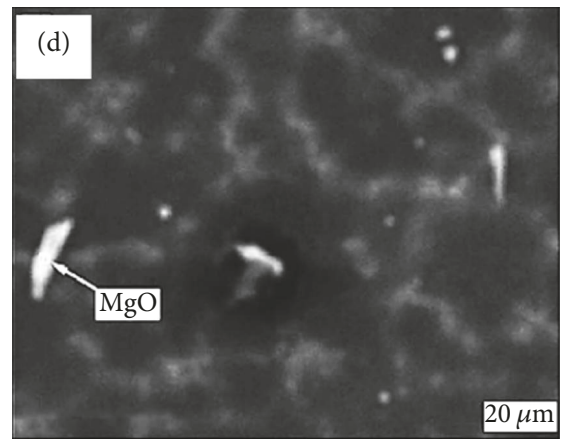

(d)

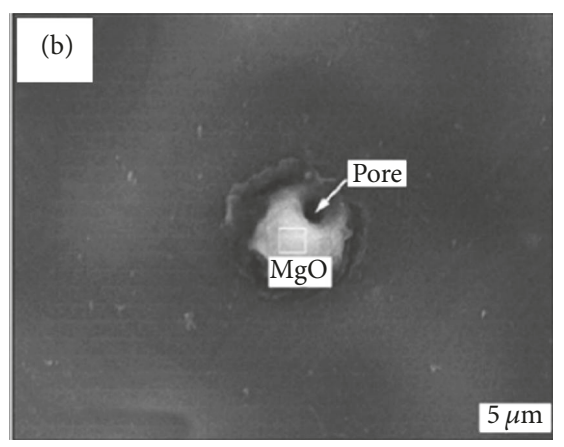

(b)

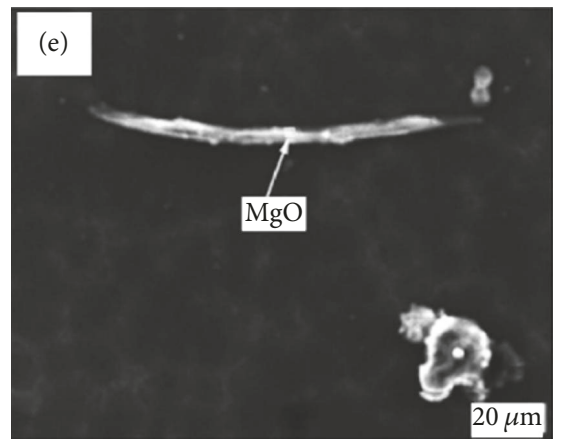

(e)

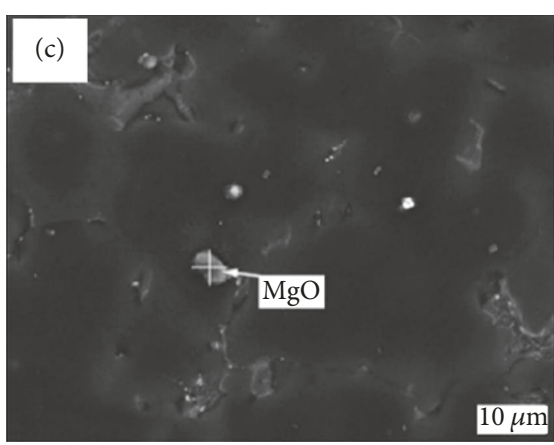

(c)

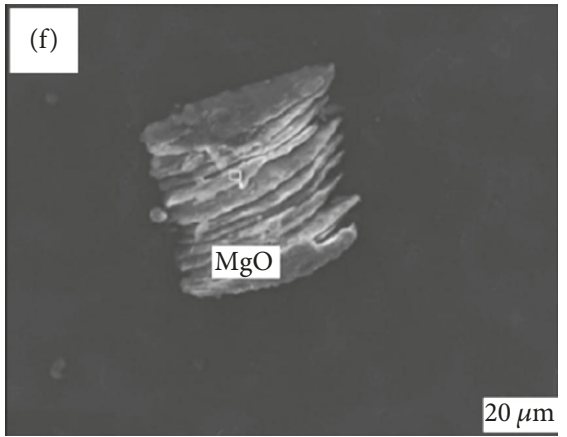

(f)

FIGURE 2: Scanning electron microscope (SEM) images of MgO inclusions in Mg-Gd-Y-Zr: (a) Z-shaped, (b) spherical, (c) block, (d) rod-like, (e) needle-like, and (f) lamellar MgO [56].

corrosive attack, which keeps the corrosion rate very slow. When levels are above the tolerance limits, $\mathrm{Fe}, \mathrm{Ni}$, and $\mathrm{Cu}$ in $\mathrm{Mg}$ alloys significantly increase the corrosion rate due to the low solubility of these elements and their distinctly more noble position in the electrochemical series [66]. Atrens et al. found that impurity elements notably accelerate saltwater corrosion of $\mathrm{Mg}$ binary alloys [114]. Recent studies have shown that adding silicon $(\mathrm{Si})$ to the reactive impurity elements $\mathrm{Fe}, \mathrm{Ni}$, and $\mathrm{Cu}$ is detrimental to corrosion, as it plays a critical role in promoting the formation and growth of Fe-rich particles. Lee et al. suggested that corrosion of $\mathrm{Mg}$ is dependent on the content ratio of impurities, such as the Fe/Mn ratio, rather than their absolute content. As the Fe/Mn ratio increases, the high rate of corrosion stage extends [5]. In addition to accelerating corrosion, excessive impurity elements are also harmful to biocompatibility. For example, Ni leaching into the body has toxic biological effects and high levels of $\mathrm{Cu}$ exert a toxic effect at cell surfaces [115]. In order to reduce impurity during casting and refining, the crucible, stirrer, and mold containing no such elements are prudently utilized [31].

As the chemical properties of $\mathrm{Mg}$ alloys are very active, a large amount of nonmetallic inclusions is also produced during casting and refining which act as additional major impurities in $\mathrm{Mg}$ alloys [116]. The main nonmetallic inclusions include $\mathrm{MgO}, \mathrm{Mg}_{3} \mathrm{~N}_{2}, \mathrm{MgF}_{2}, \mathrm{MgS}_{2}$, and $\mathrm{AlF}_{3}$. These nonmetallic impurities primarily come from the oxidation of $\mathrm{Mg}$ alloys in ambient atmospheres. For example, $\mathrm{MgO}$, a common $\mathrm{Mg}$ alloy inclusion, is produced when $\mathrm{Mg}$ and $\mathrm{O}_{2}$ react in the air. Figure 2 illustrates the different morphologies of $\mathrm{MgO}$ impurities in Mg-Gd-Y-Zr alloy [56]. $\mathrm{Mg}_{3} \mathrm{~N}_{2}$ is attributed to $\mathrm{Mg}$ and $\mathrm{N}_{2}$ combining in the air. When $\mathrm{Mg}$ alloys smelt under the protection of $\mathrm{SF}_{6}$ gas, $\mathrm{MgF}_{2}$ and $\mathrm{MgS}$ inclusions may form from reactions between $\mathrm{SF}_{6}$ and liquid $\mathrm{Mg}$. As the nonmetallic impurities significantly reduce the castability, mechanical properties, and corrosion resistance of $\mathrm{Mg}$ alloys, purification technology is undergoing continuous development [117]. The common methods of purifying $\mathrm{Mg}$ alloys include gas purge, flux purification, filtering purification, RE purification, and electromagnetic purification methods [116].

\section{Surface Modifications of Magnesium Alloys}

In order to efficiently improve the corrosion resistance of $\mathrm{Mg}$ alloys in physiological environments, as well as maintain their mechanical integrity and ameliorate interfacial biocompatibility, various surface modifications have been developed. Distinct from alloying techniques, surface modifications directly insulate $\mathrm{Mg}$ alloys from the surrounding biological environment and prevent the penetration of body fluid into substrates $[100,118,119]$. Based on whether a new phase is generated on the surface of the $\mathrm{Mg}$ alloys, the methods of surface modification can be classified into three categories: chemical modifications, physical modifications, and a combination of these two methods [120].

3.1. Chemical Modifications. Chemical modifications are defined as new phases covering the surface of $\mathrm{Mg}$ alloys 


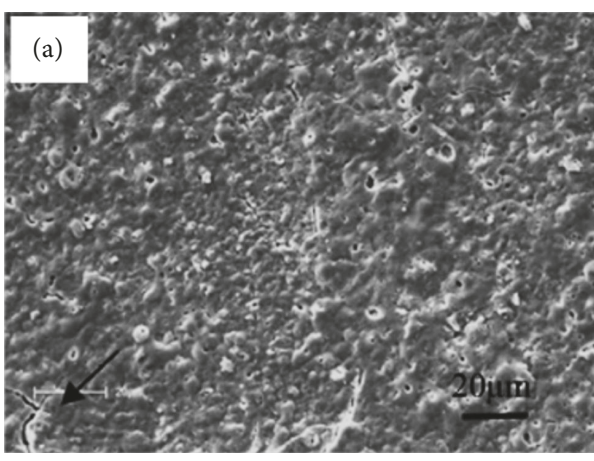

(a)

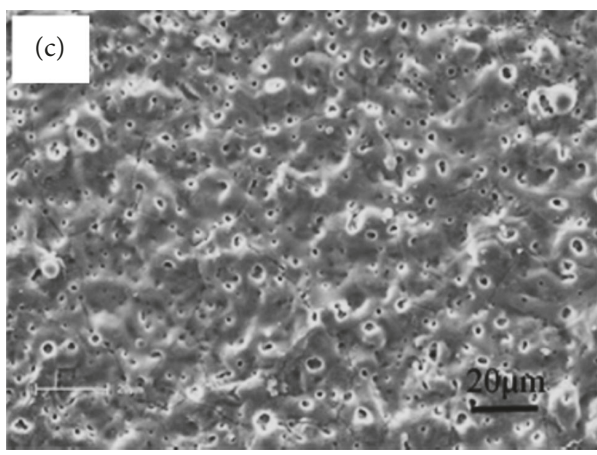

(c)

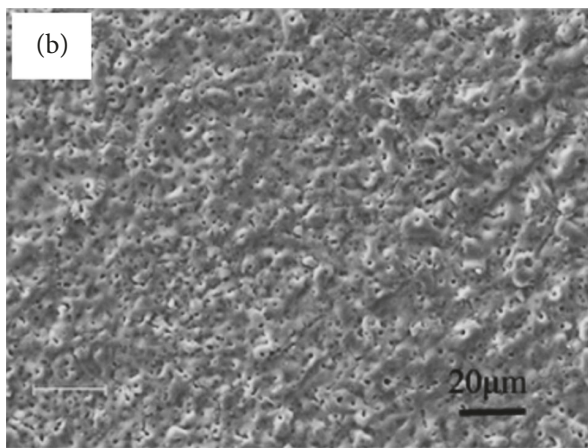

(b)

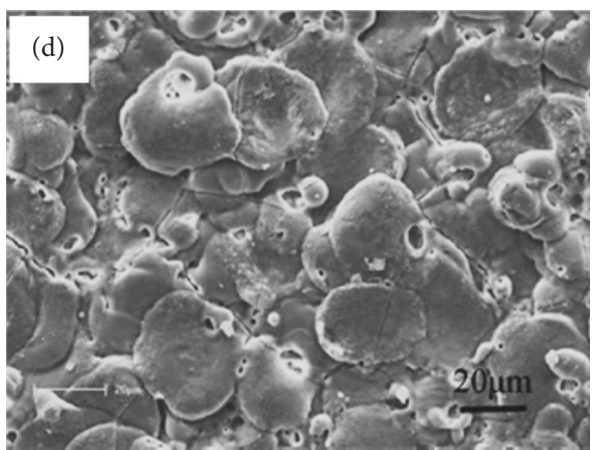

(d)

FIGURE 3: Surface morphologies of ZK60 alloy coated by microarc oxidation at voltages of (a) $230 \mathrm{~V}$, (b) $300 \mathrm{~V}$, (c) $370 \mathrm{~V}$, and (d) $450 \mathrm{~V}$ [29]. Some microcracks can be found on the $230 \mathrm{~V}$ coating, as marked by the black arrow in (a).

that are synthesized through chemical or electrochemical reactions. This method removes the native oxide layer that has fewer passive properties, such as an inability to efficiently protect against corrosion, but forms easily due to the high reactivity of $\mathrm{Mg}$ matrix. Chemical modifications generally include acid etching, alkaline heat treatment, fluoride treatment, anodic oxidation, and microarc oxidation (MAO) [120].

Acid etching is a pretreatment method commonly used to remove the coarse scale produced during manufacturing and replace the native oxide layer with a more compact passivated layer [121]. Turhan et al. reported that acid etching with a $2.5 \% \mathrm{H}_{2} \mathrm{SO}_{4}$ solution greatly enhances the resistance of AZ91D alloys to degradation [122]. In addition, alkaline heat treatment, a simple and economical method, creates a $\mathrm{Mg}(\mathrm{OH})_{2}$ barrier layer on substrate surface that slows down the corrosion rate of $\mathrm{Mg}$ alloy [123]. It has been reported that the corrosion rate of $\mathrm{Mg}$ is decreased through $\mathrm{NaOH}$ treatment, where an $\mathrm{NaOH}$ concentration of $1 \mathrm{M}$ leads to the slowest corrosion rate, through the formation of a protective layer $[123,124]$. Fluoride treatment of $\mathrm{Mg}$ alloys replaces the original oxide film with a thin and more homogeneous $\mathrm{MgF}_{2}$ layer with higher polarization resistance. The advantages of the $\mathrm{MgF}_{2}$ layer include a high density, low water solubility, and nontoxicity when fluorine ions are released into the host organism. Witte found out that $\mathrm{MgF}_{2}$ coating slows in vivo corrosion of LAE442 alloy without observably elevating fluoride concentrations in the adjacent bone [125]. Moreover, fluoride can stimulate osteoblast proliferation, increase new mineral deposition in cancellous bones, and decrease the solubility of bone tissue upon incorporation into the bone [88]. An experimental study in dogs found that fluoride-modified implant surfaces promote osteointegration during the early phase of healing following installation of the implant [126].

Anodic oxidation is an electrochemical process that produces a thick and stable oxide film on metals. Lei et al. created an $\mathrm{Mg}$ oxide film on AZ31B Mg alloy by anodic oxidation at a constant current. This film efficiently delays degradation of AZ31B Mg alloy without having any adverse effects on osteoblast proliferation or new bone formation [127]. MAO is a high-voltage plasma-assisted anodic oxidation process that is widely employed to modify the surface of biodegradable $\mathrm{Mg}$ alloys. MAO coatings are very hard and have good wear resistance, moderate corrosion resistance, and better thermal stability and dielectric properties [128]. Lin et al. prepared forsterite-containing MAO coatings on ZK60 Mg alloy to slow down degradation and improve the biological properties of the alloy. It was found that the resistance to corrosion from the MAO coating increased as the preparation voltage increased. Compared to bare ZK60 Mg alloy, MAOcoated ZK60 has a dramatically lower hemolytic ratio and no cytotoxicity to L929 cells. Figure 3 presents the surface morphologies of ZK60 alloy with MAO coatings generated at different voltages [29].

3.2. Physical Modifications. Different from the chemical methods, no chemical bonds were formed between the 
surface and the substrates for physical modifications. The modifications aim to offer a physical barrier to improve the corrosion resistance of magnesium substrates. The physical modifications can be performed by introducing apatite coatings, polymer coatings, laser surface processing, or cold spray coatings $[120,129]$.

Apatite is a main inorganic component of natural bone. It can remarkably promote the recovery of bone fracture due to its excellent bioactivity. Besides, apatite also could improve the degradation resistance of implants as a protective layer due to its relatively low solubility and high thermal stability [130].

As one important member of the apatite family, hydroxyapatite (HA) shows the closest chemical composition with bone mineral and is widely used to coat magnesium alloys for bone repair [120]. Wang et al. developed an HA coating on ZK60 Mg alloy with HA and found that it prevented the degradation of the alloy and increased cytocompatibility for L929 cells, rendering ZK60 alloy more suitable for orthopedic applications. In addition, no significant deterioration in compression strength was noted in the coated alloy compared to the uncoated one [131].

Polymer coatings are also promising $\mathrm{Mg}$ alloy modifications for use in orthopedic applications. Gray-Munro et al. explored the influence of polymer coating on the corrosion rate of AZ31 Mg alloy in SBF using PLA, which is a semicrystalline biodegradable polymer, and found that the coating prevented corrosion, especially during the early stages of implantation [90].

Laser surface processing, which uses a high-energy laser beam, has also been employed to regulate biodegradation of $\mathrm{Mg}$ alloys and has been found to cause secondary phase dissolution and create a fine grained structure. Coy et al. found significant dissolution of the second phase of $\mathrm{Mg}_{17} \mathrm{Al}_{12}$ in AZ91D when using laser surface processing [132]. Similar results were reported by Guo et al. and Khalfaui et al. for WE43 and ZE41 alloys using laser processing [133, 134]. Appreciable improvements in resistance to corrosion have also been observed for the aforementioned modified alloys [135].

Cold spray technology is a viable method for surface engineering of $\mathrm{Mg}$ alloys. The deposition of cold spray coatings involves ballistic impingement of particles, usually ranging in size from 1 to $100 \mu \mathrm{m}$, accelerated by a high-velocity gas stream and sprayed towards the substrate surface. A low temperature process, cold spray is particularly suitable for the deposition of bioactive coatings on $\mathrm{Mg}$ alloys, making it possible to depress oxidation and phase transformation of the substrate. Noorakma et al. recently studied the deposition of HA on an AZ51 alloy using a modified cold spray process and found that this modification helped retain the characteristics of HA. Immersion in SBF for up to 14 days revealed that HA-coated AZ51 alloy was bioactive and facilitated apatite formation [136].

3.3. Chemical and Physical Modifications. Considering the limitations of single chemical and physical treatments, composite modifications that involve both chemical and physical treatments have been gaining increasing attention. It has been reported that double-modified layers effectively improve biodegradation resistance of substrates and control degradation rates over a larger range [120]. Guo et al. fabricated an $\mathrm{MAO} /$ poly-L-lactic acid (PLLA) composite coating on WE42 alloy surfaces by sealing PLLA to the MAO coating through physical interlocking. This MAO/PLLA-modified WE42 alloy was found to have good corrosion resistance and cytocompatibility. Figure 4 presents the surface morphologies of WE42, WE42-MAO, and WE42-MAO/PLLA before and after being submerged in Hank's solution for four days [57]. As shown in Figures 4(a) and 4(d), WE42 Mg alloy was severely corroded by Hank's solution. The surface of the WE42 experienced strong corrosion as shown in Figure 4(d) based on deeper and wider cracks and holes, as well as the deposition of white flocculent accumulations. Micropores and microcracks were randomly distributed on the surface of the MAO coating (Figure 4(b)). After submersion, the MAO coating was corroded with little white flocculent deposits on the surface (Figure 4(e)). The biocompatible PLLA sealing layer was smooth and uniform, overlaying cracks and pores on the surface of the MAO coating (Figure 4(c)). As shown in Figure 4(f), there were no notable changes to the surface of the MAO/PLLA, where the surface of the WE42-MAO/PLLA sample remained covered with an intact layer that displayed no signs of corrosion.

\section{Biological Performance of Biodegradable Magnesium Alloys as Bone Implants}

It is critical for biodegradable $\mathrm{Mg}$ alloys to have good biocompatibility in the body in order to be used in the clinic [130]. Therefore, the in vitro and in vivo biological performance of biodegradable $\mathrm{Mg}$ alloys has been examined for many years [137].

4.1. In Vitro Biological Performance. In vitro experiments can be used to simulate and predict corrosion and biocompatibility of $\mathrm{Mg}$ alloys in vivo [138]. Compared to in vivo experiments, in vitro experiments are more convenient and can provide quick and reasonable feedback concerning efficacy [139]. Gu et al. studied the in vitro corrosion and biocompatibility of nine binary Mg-1X (wt.\%, X = Al, Ag, In, $\mathrm{Mn}, \mathrm{Si}, \mathrm{Sn}, \mathrm{Y}, \mathrm{Zn}$, and Zr) alloys using SEM, X-ray diffraction, tensile tests, immersion tests, electrochemical corrosion tests, cell culture, and platelet adhesion. The addition of alloying elements influenced the strength and corrosion resistance of $\mathrm{Mg}$. Al, Si, Sn, Zn, and $\mathrm{Zr}$ improved the strength of $\mathrm{Mg}$, while $\mathrm{Al}, \mathrm{In}, \mathrm{Mn}, \mathrm{Zn}$, and $\mathrm{Zr}$ slowed down corrosion of as-cast Mg$\mathrm{X}$ alloys in both SBF and Hank's solutions. Conversely, Si and $\mathrm{Y}$ negatively impacted $\mathrm{Mg}$ corrosion. Cytotoxicity assays indicate that $\mathrm{Mg}-1 \mathrm{Al}, \mathrm{Mg}-1 \mathrm{Sn}$, and $\mathrm{Mg}-1 \mathrm{Zn}$ alloy extracts do not significant reduce the viability of fibroblasts (L-929 and NIH3T3), Mg-1Al, Mg-1Si, Mg-1Sn, Mg-1Y, Mg-1Zn, and $\mathrm{Mg}-1 \mathrm{Zr}$ alloy extracts do not have significant toxicity against osteoblasts (MC3T3-E1), and Mg-1Al and Mg-1Zn have no negative effects on the viability of blood vessel-related cells (ECV304 and VSMC). In hemolysis assays, Mg-1In, Mg-1Mn, $\mathrm{Mg}-1 \mathrm{Si}$, and Mg-1Y alloys had low ratios of hemolysis of less than 5\%. Adhered platelets are approximately round in 


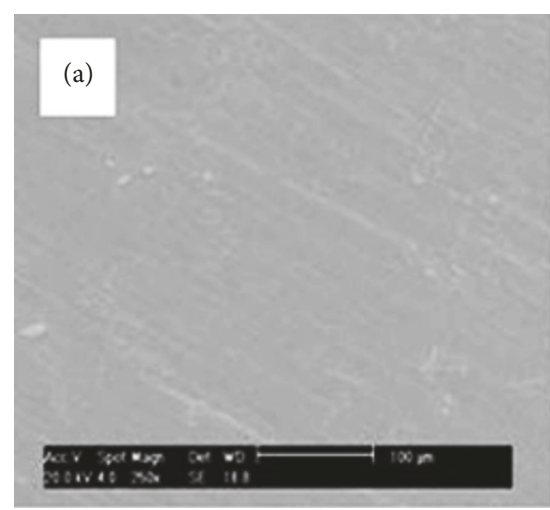

(a)

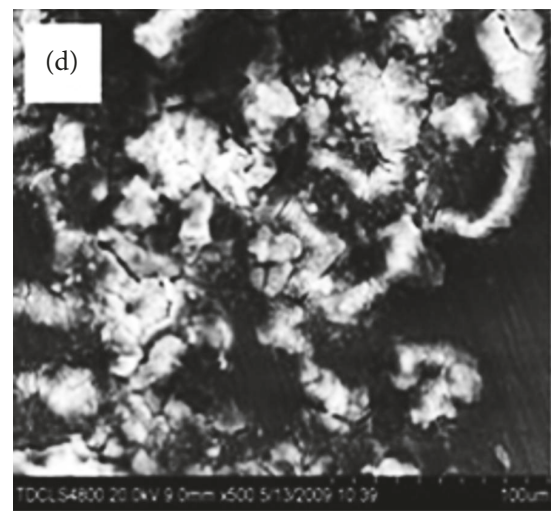

(d)

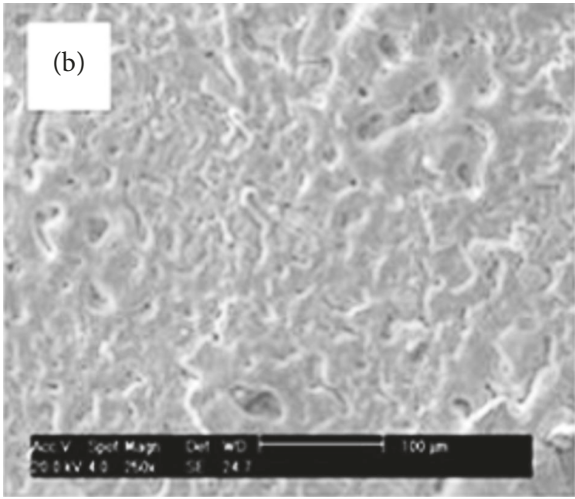

(b)

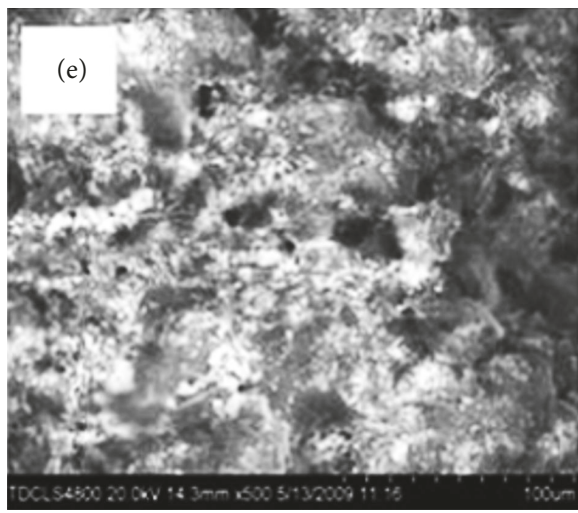

(e)

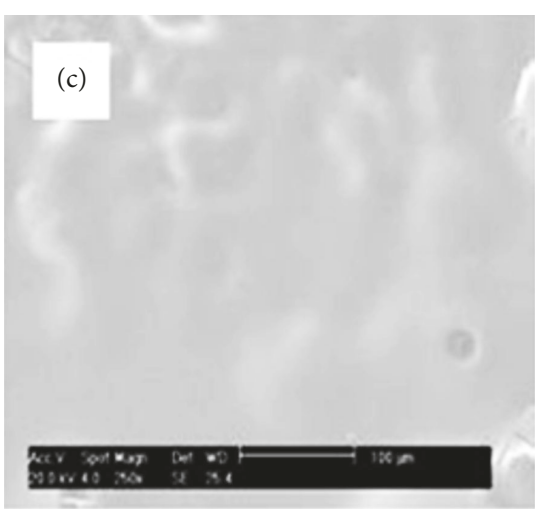

(c)

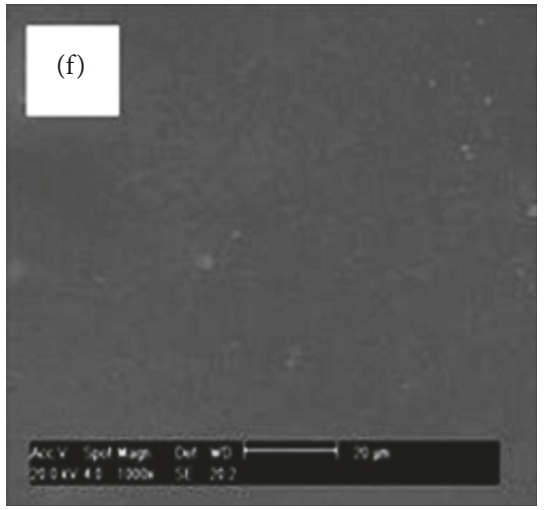

(f)

FIGURE 4: SEM images of sample surface morphology before (a) WE42, (b) WE42-MAO, and (c) WE42-MAO/PLLA and after (d) WE42, (e) WE42-MAO, and (f) WE42-MAO/PLLA were submerged in Hank's solution at $37^{\circ} \mathrm{C}(\mathrm{pH}=7.4)$ [57].

shape and have slight spreading of pseudopodia, but fewer were adhered for alloys compared to the pure $\mathrm{Mg}$ control [140]. Wang et al. investigated in vitro cellular responses and degradation of the $\mathrm{Mg}$ alloy M1A (Mg-1.42 wt.\% Mn) in SBF and albumin-containing SBF (A-SBF, $40 \mathrm{~g} / \mathrm{L}$ ). They found that the corrosion of M1A was strongly affected by the presence of albumin due to the synergistic effects of albumin adsorption and chelation. M1A samples had well-spread cells and good cell viability, implying that $\mathrm{M} 1 \mathrm{~A} \mathrm{Mg}$ alloy has the potential to serve in biodegradable implants. Figure 5 presents the surface morphology of M1A after soaking in ASBF for $30 \mathrm{~min}$ [58]. Figure 5(a) suggests that the presence of albumin does not significantly influence the formation of the passivation layer within the first $0.5 \mathrm{~h}$ of immersion. However, assessments of the surface after cleaning (Figures 5(b) and 5(c)) reveal that the grain boundaries are still the preferred sites for initiation of corrosion and the corrosion was relatively uniform across the test surface. However, in vitro assays cannot completely recapitulate in vivo experiments because in vivo environments are more complex [141]. Witte et al. investigated the effects of in vitro and in vivo corrosive environments on the corrosion rates of gravity-casted AZ91D and LAE442 Mg alloys and found that corrosion was about four orders of magnitude slower in vivo than in vitro [92].
4.2. In Vivo Biological Performance. In vivo animal experiments must be performed to optimally mimic physiological environments of human body prior to clinical experiments. In vivo animal experiments help characterize local tissue reactions to $\mathrm{Mg}$-based implants through follow-up testing, including serum analysis, radiographic examination, microCT investigations, histology analysis, and implant examination [142]. Local bone responses to biodegradable Mg alloys depend on the rate of degradation, corrosion products, and stability of the $\mathrm{Mg}$ alloys.

Zhang et al. implanted Mg-Zn-Mn alloy into rats to investigate the in vivo degradation of $\mathrm{Mg}$ alloy, response of the bone to the biodegradable $\mathrm{Mg}$ implant, and effect of the degradation of $\mathrm{Mg}$ alloy on blood composition and organs. $\mathrm{Mg}-\mathrm{Zn}-\mathrm{Mn}$ alloy was found to degrade at different rates in the marrow cavity and cortical bone. New bone tissue, but not fibrous capsule, formed around the $\mathrm{Mg}$ implants 6 weeks after implantation. More new bone tissue, as well as membrane, was found around the implant 10 and 26 weeks after implantation. The degradation of the $\mathrm{Mg}-\mathrm{Zn}-\mathrm{Mn}$ implant caused little change to the blood composition, liver, and kidneys [143]. Dziuba et al. developed a new degradable $\mathrm{Mg}$ alloy, ZEK100, and explored its long-term degradation and biocompatibility in adult female New Zealand white rabbits. Importantly, ZEK100 degrades slowly in vivo. 


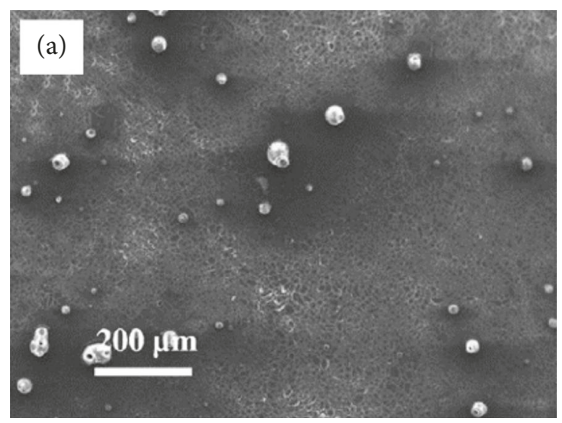

(a)

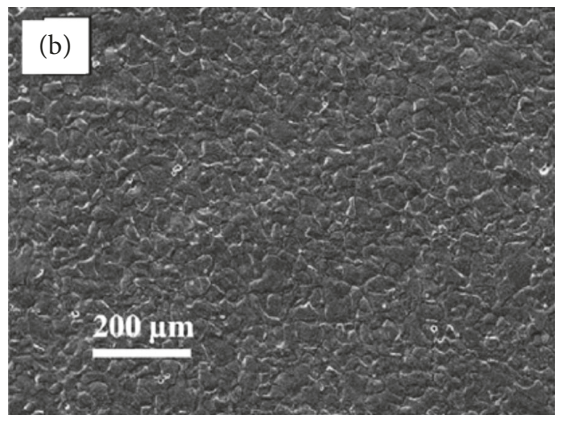

(b)

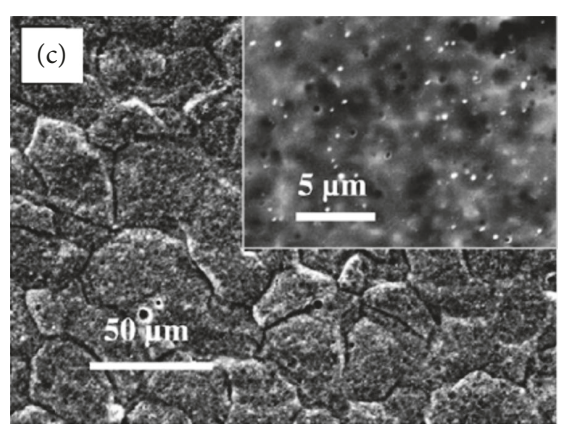

(c)

Figure 5: Surface morphology of M1A after soaking in A-SBF for 30 min: (a) original surface, (b) surface after cleaning, and (c) highmagnification view of surface after cleaning [58].

However, favorable in vivo degradation is not necessarily associated with good biocompatibility and the absence of general pathological disorders does not definitively indicate that $\mathrm{Mg}$ implants have acceptable biocompatibility. In this study, ZEK100 caused various local pathological effects in the form of severe bone alterations [142]. Chai et al. implanted $\beta$-tricalcium phosphate- (TCP-) coated AZ31 Mg alloys into the femurs of rats after predrilling with $1 \mathrm{~mm}$ hand-operated drills to evaluate implant osteogenesis and biodegradability. Figure 6 shows the SEM of the rod samples of $\beta$-TCP-coated AZ31, naked AZ31, and Ti-6Al-4V alloys after implantation for 1,4 , and 12 weeks [59]. For the $\beta$-TCP-coated Mg alloy, cells and cell secretion proteins were found on the surface after the 1st week. After 4 weeks, the rod implant was covered with a large amount of organic proteins. After 12 weeks, degradation products and cracks were thicker on the surface than at the previous timepoint. On the naked $\mathrm{Mg}$ alloy, many cracks were clearly seen after 1 week. After 4 weeks, cell secretion proteins were found on the surface. After 12 weeks, a thin excreted matrix layer that almost covered the naked $\mathrm{Mg}$ alloy sample was observed. By comparison, the $\mathrm{Ti}$ alloy surface morphology was the same at different timepoints. This demonstrates that the $\beta$-TCP coating slows down degradation of naked $\mathrm{Mg}$ alloy at the early stages of implantation and confirms that the $\beta$-TCP coating greatly improved osteoconductivity and osteogenesis in the early 12 week postoperation period.

\section{Conclusion and Suggestions}

This review presented and discussed recent research and developments on $\mathrm{Mg}$ alloy for use in bone repair. Significant efforts have been made to improve the mechanical properties, corrosion resistance, and biocompatibility of $\mathrm{Mg}$ alloys through alloying design and surface modification. In summary, there is great potential for the future use of $\mathrm{Mg}$ alloys in bone repair as surgical implant materials. Although a vast number of studies have focused on biodegradable $\mathrm{Mg}$ alloy implants, which are expected to reduce the need for follow-up surgeries and lead to safer, more effective bone repair, improvements are needed and suggestions for future research are presented in this article.
To better mimic the performance of $\mathrm{Mg}$ alloys in physiological environments, targeted animal models need to be created. For example, an ovariectomized rat model was built to explore the effects of $10 \%$ SrHA coatings on implant fixation and prophylaxis of postmenopausal osteoporosis [144]. Waselau et al. created triangular fragments with $1 \mathrm{~cm}$ long arms using a Y-shaped osteotomy of the second and fourth metatarsal bones in horses and compared the effects of biodegradable $\mathrm{Mg}$ phosphate cement, Ca phosphate cement, and no cement on bone repair, biocompatibility, and bone adhesion [145]. The above-described animal models, as well as traditional bone damage models, should be adapted for future studies on the use of $\mathrm{Mg}$ alloys for bone repair.

With regard to the feasibility of using biodegradable $\mathrm{Mg}$ alloys in bone repair surgery, the interlocking of bone implants, such as nails, screws, needles, and plates, into the surrounding bone must be biomechanically tested. It is important to assess the strength of bone-implant fixation in vivo by comparing the implants of interest with commonly used implants. Erdmann et al. compared the biomechanical properties of degradable Mg-0.8Ca alloy and commonly used stainless steel (S316L) screws using uniaxial pull-out tests in an MTS 858 Mini Bionix at a rate of $0.1 \mathrm{~mm} / \mathrm{s}$. Mg-0.8Ca had good tolerability and biomechanical properties comparable to S316L during the first 2-3 weeks after implantation. Therefore, its use as a biodegradable implant is conceivable [23]. Castellani et al. investigated the bone-implant interface strength and osseointegration of a novel biodegradable $\mathrm{Mg}$ alloy (Mg-Y-Nd-HRE, based on WE43) and compared it to a titanium control (Ti-6Al-7Nb). By comparison, Mg-YNd-HRE alloy not only enhanced the response of the bone but also had excellent interfacial strength, thus fulfilling two critical requirements for use in bone implants [146]. Creating a mechanically stable bone-implant interface is particularly critical to the successful clinical use of bone repair implants. Therefore, additional biomechanical research is required in the future.

Because of the complexity of the physiological environment of the human body, long-term studies are required to investigate in vivo degradation and biocompatibility of biodegradable $\mathrm{Mg}$ alloys. In addition to the above suggestions, future work should focus on the topics described 

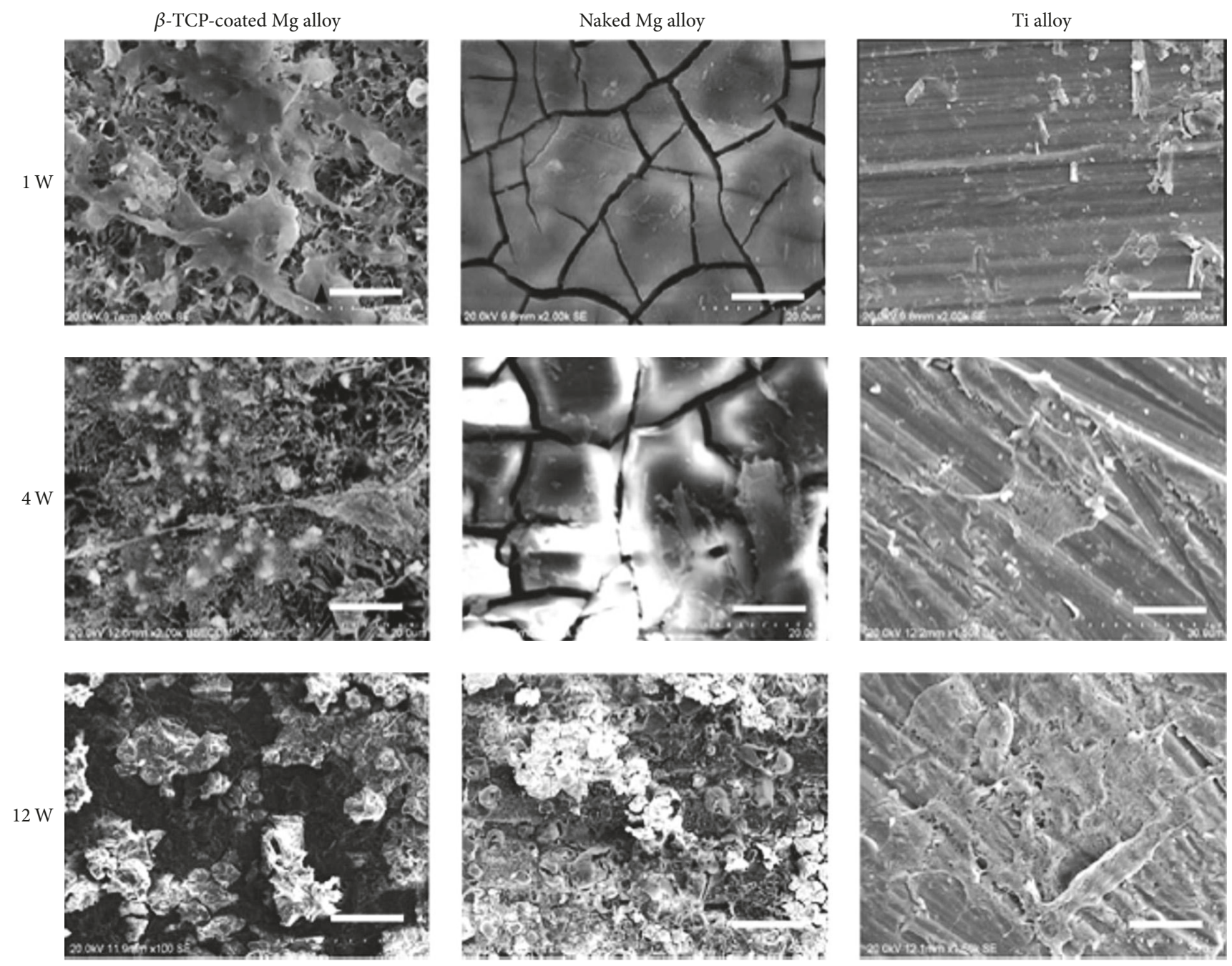

FIGURE 6: SEM images of $\beta$-tricalcium phosphate-coated AZ31, naked AZ31, and Ti-6Al-4V alloy rod samples after implantation for 1, 4, and 12 weeks. Scale bar $=5 \mu \mathrm{m}$ [59].

below. The development of controllable degradation of biodegradable $\mathrm{Mg}$ alloys via either novel or traditional strategies, such as processing control and bionic coating, is required. An example is the development of biofunctional alloy systems using human essential nutrients in alloying [81]. In addition, because bone vasculature plays a vital role in bone development, remodeling, and homeostasis, angiogenesis of Mg-based implants should also be a focus of research [147]. In order to obtain more reliable biosafety information and prepare for clinical trials, it is necessary to investigate the longer-term effects of $\mathrm{Mg}$ alloy implants on tissues and organs. The in vivo performance of biodegradable $\mathrm{Mg}$ alloys will likely improve in the near future and, therefore, Mg alloy implants will play more important roles in the treatment of orthopedic diseases.

\section{Conflicts of Interest}

The authors declare that they have no conflicts of interest.

\section{Acknowledgments}

The present work was supported by Zhejiang Projects for Postdoctoral Research Preferred Funds (2017), the National Natural Science Foundation of China (81572113, 51501218), Guangdong Provincial Science and Technology Projects (2016A020222007), Shenzhen Science and Technology Research Funding (JCYJ20160229195249481, JCYJ20160429185449249, and JCYJ20160608153641020), Shenzhen-Hong Kong Technology Cooperation Funding Scheme (SGLH20150213143207910), and Shenzhen Peacock Programs 110811003586331.

\section{References}

[1] I. H. Kalfas, "Principles of bone healing," Neurosurgical Focus, vol. 10, no. 4, p. E1, 2001.

[2] K. M. Nuss and B. v. Rechenberg, "Biocompatibility Issues with Modern Implants in Bone - A Review for Clinical Orthopedics," The Open Orthopaedics Journal , vol. 2, no. 1, pp. 66-78, 2008. 
[3] R. W. Westerman and B. E. Scammell, "Principles of bone and joint injuries and their healing," Surgery, vol. 30, no. 2, pp. 5460, 2012.

[4] C. Liu, P. Wan, L. L. Tan, K. Wang, and K. Yang, "Preclinical investigation of an innovative magnesium-based bone graft substitute for potential orthopaedic applications," Journal of Orthopaedic Translation, vol. 2, no. 3, pp. 139-148, 2014.

[5] J.-Y. Lee, G. Han, Y.-C. Kim et al., "Effects of impurities on the biodegradation behavior of pure magnesium," Metals and Materials International, vol. 15, no. 6, pp. 955-961, 2009.

[6] L. Tan, X. Yu, P. Wan, and K. Yang, "Biodegradable Materials for Bone Repairs: A Review," Journal of Materials Science and Technology, vol. 29, no. 6, pp. 503-513, 2013.

[7] J. G. Stark, "Use of selective estrogen receptor modulator for joint fusion and other healing," WO 136956, 2001.

[8] G. M. Calori, E. Mazza, M. Colombo, and C. Ripamonti, “The use of bone-graft substitutes in large bone defects: any specific needs?" Injury, vol. 42, supplement 2, pp. S56-S63, 2011.

[9] J. Van der Stok, E. M. M. Van Lieshout, Y. El-Massoudi, G. H. Van Kralingen, and P. Patka, "Bone substitutes in the Netherlands-a systematic literature review," Acta Biomaterialia, vol. 7, no. 2, pp. 739-750, 2011.

[10] J. A. Auer, B. V. Rechenberg, M. Bohner, and M. HofmannAmtenbrink, "Bone Grafts and Bone Replacements," Equine Surgery, pp. 1081-1096, 2012.

[11] H.-M. Kim, "Ceramic bioactivity and related biomimetic strategy," Current Opinion in Solid State \& Materials Science, vol. 7, no. 4-5, pp. 289-299, 2003.

[12] A. G. Dias, M. A. Lopes, I. R. Gibson, and J. D. Santos, "In vitro degradation studies of calcium phosphate glass ceramics prepared by controlled crystallization," Journal of Non-Crystalline Solids, vol. 330, no. 1-3, pp. 81-89, 2003.

[13] S. Aoki, S. Yamaguchi, A. Nakahira, and K. Suganuma, "A new approach to an artificial joint based on bio-cartilage/porous $ß$ tricalcium phosphate system," Journal of the European Ceramic Society, vol. 23, no. 15, pp. 2939-2946, 2003.

[14] K. R. Mohamed, H. H. Beherei, and Z. M. El-Rashidy, "In vitro study of nano-hydroxyapatite/chitosan-gelatin composites for bio-applications," Journal of Advanced Research, vol. 5, no. 2, pp. 201-208, 2014.

[15] C. P. Yoganand, V. Selvarajan, V. Cannillo et al., "Characterization and in vitro-bioactivity of natural hydroxyapatite based bio-glass-ceramics synthesized by thermal plasma processing," Ceramics International, vol. 36, no. 6, pp. 1757-1766, 2010.

[16] P. V. Giannoudis, H. Dinopoulos, and E. Tsiridis, "Bone substitutes: an update," Injury, vol. 36, supplement 3, pp. S20-S27, 2005.

[17] O. Böstman and H. Pihlajamäki, "Clinical biocompatibility of biodegradable orthopaedic implants for internal fixation: a review," Biomaterials, vol. 21, no. 24, pp. 2615-2621, 2000.

[18] H. Chai, L. Guo, X. Wang et al., "Antibacterial effect of 317L stainless steel contained copper in prevention of implant-related infection in vitro and in vivo," Journal of Materials Science: Materials in Medicine, vol. 22, no. 11, pp. 2525-2535, 2011.

[19] L. Nan and K. Yang, "Cu Ions Dissolution from Cu-bearing Antibacterial Stainless Steel," Journal of Materials Science and Technology, vol. 26, no. 10, pp. 941-944, 2010.

[20] T. Shirai, H. Tsuchiya, T. Shimizu, K. Ohtani, Y. Zen, and K. Tomita, "Prevention of pin tract infection with titanium-copper alloys," Journal of Biomedical Materials Research Part B: Applied Biomaterials, vol. 91, no. 1, pp. 373-380, 2009.
[21] M. Nakai, M. Niinomi, and D. Ishii, "Mechanical and biodegradable properties of porous titanium filled with polyL-lactic acid by modified in situ polymerization technique," Journal of the Mechanical Behavior of Biomedical Materials, vol. 4, no. 7, pp. 1206-1218, 2011.

[22] M. P. Staiger, A. M. Pietak, J. Huadmai, and G. Dias, "Magnesium and its alloys as orthopedic biomaterials: a review," Biomaterials, vol. 27, no. 9, pp. 1728-1734, 2006.

[23] N. Erdmann, N. Angrisani, J. Reifenrath et al., "Biomechanical testing and degradation analysis of $\mathrm{MgCa} 0.8$ alloy screws: a comparative in vivo study in rabbits," Acta Biomaterialia, vol. 7, no. 3, pp. 1421-1428, 2011.

[24] H. Tschernitschek, L. Borchers, and W. Geurtsen, "Nonalloyed titanium as a bioinert metal-a review," Quintessence International, vol. 36, no. 7, pp. 523-530, 2005.

[25] D. Hong, P. Saha, D.-T. Chou et al., "In vitro degradation and cytotoxicity response of $\mathrm{Mg}-4 \% \mathrm{Zn}-0.5 \% \mathrm{Zr}$ (ZK40) alloy as a potential biodegradable material," Acta Biomaterialia, vol. 9, no. 10, pp. 8534-8547, 2013.

[26] K. W. K. Yeung and K. H. M. Wong, Biodegradable Metallic Materials for Orthopaedic Implantations: A Review, vol. 20, IOS Press, 2012

[27] S. Shadanbaz and G. J. Dias, "Calcium phosphate coatings on magnesium alloys for biomedical applications: a review," Acta Biomaterialia, vol. 8, no. 1, pp. 20-30, 2012.

[28] H. Yang, X. Yan, M. Ling, Z. Xiong, C. Ou, and W. Lu, "In vitro corrosion and cytocompatibility properties of nano-Whisker hydroxyapatite coating on magnesium alloy for bone tissue engineering applications," International Journal of Molecular Sciences, vol. 16, no. 3, pp. 6113-6123, 2015.

[29] X. Lin, L. Tan, Q. Zhang et al., "The in vitro degradation process and biocompatibility of a ZK60 magnesium alloy with a forsterite-containing micro-arc oxidation coating," Acta Biomaterialia, vol. 9, no. 10, pp. 8631-8642, 2013.

[30] D. Persaud-Sharma and A. McGoron, "Biodegradable magnesium alloys: a review of material development and applications," Journal of Biomimetics, Biomaterials and Tissue Engineering, vol. 12 , no. 1, pp. 25-39, 2011.

[31] H. Waizy, J.-M. Seitz, J. Reifenrath et al., "Biodegradable magnesium implants for orthopedic applications," Journal of Materials Science, vol. 48, no. 1, pp. 39-50, 2013.

[32] M. Bornapour, M. Celikin, M. Cerruti, and M. Pekguleryuz, "Magnesium implant alloy with low levels of strontium and calcium: The third element effect and phase selection improve biocorrosion resistance and mechanical performance," Materials Science and Engineering C: Materials for Biological Applications, vol. 35, no. 1, pp. 267-282, 2014.

[33] D. Xue, Y. Yun, M. J. Schulz, and V. Shanov, "Corrosion protection of biodegradable magnesium implants using anodization," Materials Science and Engineering C: Materials for Biological Applications, vol. 31, no. 2, pp. 215-223, 2011.

[34] C. K. Seal, K. Vince, and M. A. Hodgson, "Biodegradable surgical implants based on magnesium alloys - A review of current research," in Proceedings of the IOP Conference Series: Materials Science and Engineering, IOP Publishing, 2009.

[35] H. S. Brar, J. Wong, and M. V. Manuel, "Investigation of the mechanical and degradation properties of $\mathrm{Mg}-\mathrm{Sr}$ and $\mathrm{Mg}-\mathrm{Zn}$ Sr alloys for use as potential biodegradable implant materials," Journal of the Mechanical Behavior of Biomedical Materials, vol. 7, pp. 87-95, 2012. 
[36] N. Li and Y. Zheng, "Novel Magnesium Alloys Developed for Biomedical Application: A Review," Journal of Materials Science and Technology, vol. 29, no. 6, pp. 489-502, 2013.

[37] Y. Chen, Z. Xu, C. Smith, and J. Sankar, "Recent advances on the development of magnesium alloys for biodegradable implants," Acta Biomaterialia, vol. 10, no. 11, pp. 4561-4573, 2014.

[38] Y. Yun, Z. Dong, D. Yang et al., "Biodegradable Mg corrosion and osteoblast cell culture studies," Materials Science and Engineering C: Materials for Biological Applications, vol. 29, no. 6, pp. 1814-1821, 2009.

[39] S. Agarwal, J. Curtin, B. Duffy, and S. Jaiswal, "Biodegradable magnesium alloys for orthopaedic applications: A review on corrosion, biocompatibility and surface modifications," Materials Science and Engineering C: Materials for Biological Applications, vol. 68, pp. 948-963, 2016.

[40] G. Song and S. Song, "A possible biodegradable magnesium implant material," Advanced Engineering Materials, vol. 9, no. 4, pp. 298-302, 2007.

[41] X. N. Gu, W. Zheng, Y. Cheng, and Y. F. Zheng, "A study on alkaline heat treated $\mathrm{Mg}$-Ca alloy for the control of the biocorrosion rate," Acta Biomaterialia, vol. 5, no. 7, pp. 27902799, 2009.

[42] A. W. Lloyd, "Interfacial bioengineering to enhance surface biocompatibility," Medical Device Technology, vol. 13, no. 1, pp. 18-21, 2002.

[43] R. M. Smith, "AO Principles of Fracture Management," The Journal of Bone \& Joint Surgery, vol. 84, no. 7, p. 1293, 2002.

[44] T. Hassel, F.-W. Bach, C. Krause, and P. Wilk, "Corrosion protection and repassivation after the deformation of magnesium alloys coated with a protective magnesium fluoride layer," in Proceedings of the 2005 TMS Annual Meeting, pp. 485-490, usa, February 2005.

[45] J. Kuhlmann, I. Bartsch, E. Willbold et al., "Fast escape of hydrogen from gas cavities around corroding magnesium implants," Acta Biomaterialia, vol. 9, no. 10, pp. 8714-8721, 2013.

[46] H. Wang and Z. Shi, "In vitro biodegradation behavior of magnesium and magnesium alloy," Journal of Biomedical Materials Research Part B: Applied Biomaterials, vol. 98, no. 2, pp. 203209, 2011.

[47] J. J. Huang and K. Yang, "Research on magnesium alloys for bio-medical applications," Materials Review, vol. 20, pp. 67-69, 2006.

[48] F. Witte, N. Hort, C. Vogt et al., "Degradable biomaterials based on magnesium corrosion," Current Opinion in Solid State \& Materials Science, vol. 12, no. 5-6, pp. 63-72, 2008.

[49] P. Gill, N. Munroe, R. Dua, and S. Ramaswamy, "Corrosion and Biocompatibility Assessment of Magnesium Alloys," Journal of Biomaterials and Nanobiotechnology, vol. 03, no. 01, pp. 10-13, 2012.

[50] H. Hornberger, S. Virtanen, and A. R. Boccaccini, "Biomedical coatings on magnesium alloys - A review," Acta Biomaterialia, vol. 8, no. 7, pp. 2442-2455, 2012.

[51] J. Chen, L. Tan, and K. Yang, "Recent advances on the development of biodegradable magnesium alloys: a review," Materials Technology, vol. 31, no. 12, pp. 681-688, 2016.

[52] M. Paramsothy and S. Ramakrishna, "Biodegradable Materials for Clinical Applications: A Review," Reviews in Advanced Sciences and Engineering, vol. 4, no. 3, pp. 221-238, 2015.

[53] M. Pogorielov, E. Husak, A. Solodivnik, and S. Zhdanov, "Magnesium-based biodegradable alloys: Degradation, application, and alloying elements," Interventional Medicine and Applied Science, vol. 9, no. 1, pp. 27-38, 2017.
[54] A. E. Coy, F. Viejo, P. Skeldon, and G. E. Thompson, "Susceptibility of rare-earth-magnesium alloys to micro-galvanic corrosion," Corrosion Science, vol. 52, no. 12, pp. 3896-3906, 2010.

[55] L. Wang, B.-P. Zhang, and T. Shinohara, "Corrosion behavior of AZ91 magnesium alloy in dilute $\mathrm{NaCl}$ solutions," Materials and Corrosion, vol. 31, no. 2, pp. 857-863, 2010.

[56] M.-J. Liang, G.-H. Wu, W.-J. Ding, and W. Wang, "Effect of inclusion on service properties of GW103K magnesium alloy," Transactions of Nonferrous Metals Society of China, vol. 21, no. 4, pp. 717-724, 2011.

[57] M. Guo, L. Cao, P. Lu, Y. Liu, and X. Xu, "Anticorrosion and cytocompatibility behavior of MAO/PLLA modified magnesium alloy WE42," Journal of Materials Science: Materials in Medicine, vol. 22, no. 7, pp. 1735-1740, 2011.

[58] Y. Wang, C. S. Lim, C. V. Lim, M. S. Yong, E. K. Teo, and L. N. Moh, "In vitro degradation behavior of M1A magnesium alloy in protein-containing simulated body fluid," Materials Science and Engineering C: Materials for Biological Applications, vol. 31, no. 3, pp. 579-587, 2011.

[59] H. Chai, L. Guo, X. Wang et al., "In vitro and in vivo evaluations on osteogenesis and biodegradability of a $\beta$-tricalcium phosphate coated magnesium alloy," Journal of Biomedical Materials Research Part A, vol. 100, no. 2, pp. 293-304, 2012.

[60] Q. Li, Q. Wang, Y. Wang, X. Zeng, and W. Ding, "Effect of Nd and $Y$ addition on microstructure and mechanical properties of as-cast Mg-Zn-Zr alloy," Journal of Alloys and Compounds, vol. 427, no. 1-2, pp. 115-123, 2007.

[61] Z. Huang, Q. Huang, L. Ma, J. Lin, and Z. Pang, "Effects of $\beta$ Mg17 A112 on edge crack of roll-casting AZ31B magnesium alloy plate," Rare Metal Materials and Engineering, vol. 43, no. 5, pp. 1199-1203, 2014.

[62] H. S. Kim and W. J. Kim, "Enhanced corrosion resistance of ultrafine-grained AZ61 alloy containing very fine particles of $\mathrm{Mg}_{17} \mathrm{Al}_{12}$ phase," Corrosion Science, vol. 75, pp. 228-238, 2013.

[63] Y. Wang, M. Xia, Z. Fan, X. Zhou, and G. E. Thompson, “The effect of Al8Mn5 intermetallic particles on grain size of as-cast Mg-Al-Zn AZ91D alloy," Intermetallics, vol. 18, no. 8, pp. 1683$1689,2010$.

[64] M. Jönsson, D. Thierry, and N. LeBozec, "The influence of microstructure on the corrosion behaviour of AZ91D studied by scanning Kelvin probe force microscopy and scanning Kelvin probe," Corrosion Science, vol. 48, no. 5, pp. 1193-1208, 2006.

[65] M. Aljarrah and M. Medraj, "Thermodynamic modelling of the $\mathrm{Mg}-\mathrm{Ca}, \mathrm{Mg}-\mathrm{Sr}, \mathrm{Ca}-\mathrm{Sr}$ and $\mathrm{Mg}-\mathrm{Ca}-\mathrm{Sr}$ systems using the modified quasichemical model," Calphad, vol. 32, no. 2, pp. 240-251, 2008.

[66] A. D. Südholz, N. T. Kirkland, R. G. Buchheit, and N. Birbilis, "Electrochemical properties of intermetallic phases and common impurity elements in magnesium alloys," Electrochemical and Solid-State Letters, vol. 14, no. 2, pp. C5-C7, 2011.

[67] J. H. Gao, S. K. Guan, Z. W. Ren, Y. F. Sun, S. J. Zhu, and B. Wang, "Homogeneous corrosion of high pressure torsion treated MgZn-Ca alloy in simulated body fluid," Materials Letters, vol. 65, no. 4, pp. 691-693, 2011.

[68] M. B. Yang, F. S. Pan, L. Bai et al., "Development of effects of alloy elements on morphology of Mg2Si phase in Mg-Al-Si based magnesium alloys," Hot Working Technology, vol. 1, pp. 21-23, 2007.

[69] J. Liu, C. Xia, A. Wu et al., "Microstructure and mechanical properties of Mg-5.0Y-3.0Nd-0.5Zr alloy," Special Casting \& Nonferrous Alloys, vol. 49, pp. 1021-1024, 2007. 
[70] S. M. He, L. M. Peng, X. Q. Zeng, W. J. Ding, and Y. P. Zhu, "Comparison of the microstructure and mechanical properties of a ZK60 alloy with and without 1.3 wt.\% gadolinium addition," Materials Science and Engineering: A Structural Materials: Properties, Microstructure and Processing, vol. 433, no. 1-2, pp. 175-181, 2006.

[71] H. Yang, C. Liu, P. Wan, L. Tan, and K. Yang, "Study of second phase in bioabsorbable magnesium alloys: Phase stability evaluation via Dmol3 calculation," APL Materials, vol. 1, no. 5, Article ID 052104, 2013.

[72] D. Tie, F. Feyerabend, N. Hort et al., "In vitro mechanical and corrosion properties of biodegradable Mg-Ag alloys," Materials and Corrosion, vol. 65, no. 6, pp. 569-576, 2014.

[73] L. J. M. Hirvinen, A. S. Litsky, V. F. Samii, S. E. Weisbrode, and A. L. Bertone, "Influence of bone cements on bone-screw interfaces in the third metacarpal and third metatarsal bones of horses," American Journal of Veterinary Research, vol. 70, no. 8, pp. 964-972, 2009.

[74] Y. Zheng and X. Gu, "Research activities of biomedical magnesium alloys in China," JOM: The Journal of The Minerals, Metals \& Materials Society (TMS), vol. 63, no. 4, pp. 105-108, 2011.

[75] L. Yang, Y. Huang, F. Feyerabend et al., "Microstructure, mechanical and corrosion properties of $\mathrm{Mg}-\mathrm{Dy}-\mathrm{Gd}-\mathrm{Zr}$ alloys for medical applications," Acta Biomaterialia, vol. 9, no. 10, pp. 8499-8508, 2013.

[76] N. Hort, Y. Huang, D. Fechner et al., "Magnesium alloys as implant materials-principles of property design for Mg-RE alloys," Acta Biomaterialia, vol. 6, no. 5, pp. 1714-1725, 2010.

[77] H. R. B. Rad, M. H. Idris, M. R. A. Kadir, and S. Farahany, "Microstructure analysis and corrosion behavior of biodegradable Mg-Ca implant alloys," Materials and Corrosion, vol. 33, no. 1, pp. 88-97, 2012.

[78] E. Zhang, L. Yang, J. Xu, and H. Chen, "Microstructure, mechanical properties and bio-corrosion properties of $\mathrm{Mg}$-Si($\mathrm{Ca}, \mathrm{Zn}$ ) alloy for biomedical application," Acta Biomaterialia, vol. 6, no. 5, pp. 1756-1762, 2010.

[79] L. Xu, G. Yu, E. Zhang, F. Pan, and K. Yang, "In vivo corrosion behavior of Mg-Mn-Zn alloy for bone implant application," Journal of Biomedical Materials Research Part A, vol. 83, no. 3, pp. 703-711, 2007.

[80] E. Aghion and G. Levy, "The effect of Ca on the in vitro corrosion performance of biodegradable Mg-Nd-Y-Zr alloy," Journal of Materials Science, vol. 45, no. 11, pp. 3096-3101, 2010.

[81] C. Liu, X. Fu, H. Pan et al., "Biodegradable Mg-Cu alloys with enhanced osteogenesis, angiogenesis, and long-lasting antibacterial effects," Scientific Reports, vol. 6, Article ID 27374, 2016.

[82] M. Bornapour, N. Muja, D. Shum-Tim, M. Cerruti, and M. Pekguleryuz, "Biocompatibility and biodegradability of $\mathrm{Mg}-\mathrm{Sr}$ alloys: The formation of Sr-substituted hydroxyapatite," Acta Biomaterialia, vol. 9, no. 2, pp. 5319-5330, 2013.

[83] Y. Zhao, M. I. Jamesh, W. K. Li et al., "Enhanced antimicrobial properties, cytocompatibility, and corrosion resistance of plasma-modified biodegradable magnesium alloys," Acta Biomaterialia, vol. 10, no. 1, pp. 544-556, 2014.

[84] Z. Li, X. Gu, S. Lou, and Y. Zheng, "The development of binary $\mathrm{Mg}-\mathrm{Ca}$ alloys for use as biodegradable materials within bone," Biomaterials, vol. 29, no. 10, pp. 1329-1344, 2008.

[85] D. Tie, F. Feyerabend, W.-D. Müller et al., "Antibacterial biodegradable Mg-Ag alloys," European Cells and Materials, vol. 25, pp. 284-298, 2012.
[86] C. Zhao, F. Pan, L. Zhang, H. Pan, K. Song, and A. Tang, "Microstructure, mechanical properties, bio-corrosion properties and cytotoxicity of as-extruded Mg-Sr alloys," Materials Science and Engineering C: Materials for Biological Applications, vol. 70, pp. 1081-1088, 2017.

[87] Y. Song, D. Shan, R. Chen, F. Zhang, and E.-H. Han, "Biodegradable behaviors of AZ31 magnesium alloy in simulated body fluid," Materials Science and Engineering C: Materials for Biological Applications, vol. 29, no. 3, pp. 1039-1045, 2009.

[88] T. Yan, L. Tan, D. Xiong, X. Liu, B. Zhang, and K. Yang, "Fluoride treatment and in vitro corrosion behavior of an AZ31B magnesium alloy," Materials Science and Engineering C: Materials for Biological Applications, vol. 30, no. 5, pp. 740-748, 2010.

[89] Y. Ding, C. Wen, P. Hodgson, and Y. Li, "Effects of alloying elements on the corrosion behavior and biocompatibility of biodegradable magnesium alloys: A review," Journal of Materials Chemistry B, vol. 2, no. 14, pp. 1912-1933, 2014.

[90] J. E. Gray-Munro, C. Seguin, and M. Strong, "Influence of surface modification on the in vitro corrosion rate of magnesium alloy AZ31," Journal of Biomedical Materials Research Part A, vol. 91, no. 1, pp. 221-230, 2009.

[91] A. A. Ghoneim, A. M. Fekry, and M. A. Ameer, "Electrochemical behavior of magnesium alloys as biodegradable materials in Hank's solution," Electrochimica Acta, vol. 55, no. 20, pp. 60286035, 2010.

[92] F. Witte, J. Fischer, J. Nellesen et al., "In vitro and in vivo corrosion measurements of magnesium alloys," Biomaterials, vol. 27, no. 7, pp. 1013-1018, 2006.

[93] F. Witte, V. Kaese, H. Haferkamp et al., "In vivo corrosion of four magnesium alloys and the associated bone response," Biomaterials, vol. 26, no. 17, pp. 3557-3563, 2005.

[94] R. Walter and M. B. Kannan, "In-vitro degradation behaviour of WE54 magnesium alloy in simulated body fluid," Materials Letters, vol. 65, no. 4, pp. 748-750, 2011.

[95] M. Shahzad and L. Wagner, "The role of Zr-rich cores in strength differential effect in an extruded Mg-Zn-Zr alloy," Journal of Alloys and Compounds, vol. 486, no. 1-2, pp. 103-108, 2009.

[96] X. N. Gu, N. Li, Y. F. Zheng, and L. Ruan, "In vitro degradation performance and biological response of a Mg-Zn-Zr alloy," Materials Science and Engineering: B Advanced Functional SolidState Materials, vol. 176, no. 20, pp. 1778-1784, 2011.

[97] Z. G. Huan, M. A. Leeflang, J. Zhou, L. E. Fratila-Apachitei, and J. Duszczyk, "In vitro degradation behavior and cytocompatibility of Mg-Zn-Zr alloys," Journal of Materials Science: Materials in Medicine, vol. 21, no. 9, pp. 2623-2635, 2010.

[98] Y. Li, M. Li, W. Hu, P. Hodgson, and C. Wen, "Biodegradable $\mathrm{Mg}-\mathrm{Ca}$ and $\mathrm{Mg}-\mathrm{Ca}-\mathrm{Y}$ alloys for regenerative medicine," Materials Science Forum, vol. 654-656, pp. 2192-2195, 2010.

[99] X. N. Gu, X. H. Xie, N. Li, Y. F. Zheng, and L. Qin, "In vitro and in vivo studies on a Mg-Sr binary alloy system developed as a new kind of biodegradable metal," Acta Biomaterialia, vol. 8, no. 6, pp. 2360-2374, 2012.

[100] J. Li, Y. Song, S. Zhang et al., "In vitro responses of human bone marrow stromal cells to a fluoridated hydroxyapatite coated biodegradable Mg-Zn alloy," Biomaterials, vol. 31, no. 22, pp. 5782-5788, 2010.

[101] S. Zhang, X. Zhang, C. Zhao et al., "Research on an Mg-Zn alloy as a degradable biomaterial," Acta Biomaterialia, vol. 6, no. 2, pp. 626-640, 2010. 
[102] S. Cai, T. Lei, N. Li, and F. Feng, "Effects of $\mathrm{Zn}$ on microstructure, mechanical properties and corrosion behavior of MgZn alloys," Materials Science and Engineering C: Materials for Biological Applications, vol. 32, no. 8, pp. 2570-2577, 2012.

[103] S. Zhang, J. Li, Y. Song et al., "In vitro degradation, hemolysis and MC3T3-E1 cell adhesion of biodegradable Mg-Zn alloy," Materials Science and Engineering C: Materials for Biological Applications, vol. 29, no. 6, pp. 1907-1912, 2009.

[104] Q. Peng, Y. Huang, L. Zhou, N. Hort, and K. U. Kainer, "Preparation and properties of high purity Mg-Y biomaterials," Biomaterials, vol. 31, no. 3, pp. 398-403, 2010.

[105] A. C. Hänzi, I. Gerber, M. Schinhammer, J. F. Löffler, and P. J. Uggowitzer, "On the in vitro and in vivo degradation performance and biological response of new biodegradable $\mathrm{Mg}$ Y-Zn alloys," Acta Biomaterialia, vol. 6, no. 5, pp. 1824-1833, 2010.

[106] M. B. Kannan, "Influence of microstructure on the in-vitro degradation behaviour of magnesium alloys," Materials Letters, vol. 64, no. 6, pp. 739-742, 2010.

[107] C. Liu, P. He, P. Wan et al., "The in vitro biocompatibility and macrophage phagocytosis of Mg17Al12 phase in Mg-Al-Zn alloys," Journal of Biomedical Materials Research Part A, vol. 103, no. 7, pp. 2405-2415, 2015.

[108] L. Gao, R. S. Chen, and E. H. Han, "Solid solution strengthening behaviors in binary Mg-Y single phase alloys," Journal of Alloys and Compounds, vol. 472, no. 1-2, pp. 234-240, 2009.

[109] X. Zhang, K. Zhang, X. Li et al., "Effect of solid-solution treatment on corrosion and electrochemical behaviors of Mg$15 \mathrm{Y}$ alloy in 3.5 wt.\% $\mathrm{NaCl}$ solution," Journal of Rare Earths, vol. 30, no. 11, pp. 1158-1167, 2012.

[110] J. Hofstetter, E. Martinelli, S. Pogatscher et al., "Influence of trace impurities on the in vitro and in vivo degradation of biodegradable Mg-5Zn-0.3Ca alloys," Acta Biomaterialia, vol. 23, pp. 347-353, 2015.

[111] G. Song and A. Atrens, "Understanding magnesium corrosion-a framework for improved alloy performance," Advanced Engineering Materials, vol. 5, no. 12, pp. 837-858, 2003.

[112] J. Hofstetter, E. Martinelli, A. M. Weinberg et al., "Assessing the degradation performance of ultrahigh-purity magnesium in vitro and in vivo," Corrosion Science, vol. 91, pp. 29-36, 2015.

[113] M. Liu, P. J. Uggowitzer, A. V. Nagasekhar et al., "Calculated phase diagrams and the corrosion of die-cast Mg-Al alloys," Corrosion Science, vol. 51, no. 3, pp. 602-619, 2009.

[114] A. Atrens, M. Liu, and N. I. Zainal Abidin, "Corrosion mechanism applicable to biodegradable magnesium implants," Materials Science and Engineering: B Advanced Functional SolidState Materials, vol. 176, no. 20, pp. 1609-1636, 2011.

[115] C. A. Flemming and J. T. Trevors, "Copper toxicity and chemistry in the environment: a review," Water, Air, \& Soil Pollution, vol. 44, no. 1-2, pp. 143-158, 1989.

[116] G. H. Wu, M. Sun, Wang. W. et al., "New research development on purification technology of magnesium alloys," International Journal of Nonferrous Metallurgy, vol. 20, pp. 1021-1031, 2010.

[117] H. L. Li, R. Hu, W. T. Qu et al., "The high purification of magnesium and its alloys," Special Casting \& Nonferrous Alloys, 1, pp. 88-89, 2001.

[118] J. Yang, F. Cui, and I. S. Lee, "Surface modifications of magnesium alloys for biomedical applications," Annals of Biomedical Engineering, vol. 39, no. 7, pp. 1857-1871, 2011.

[119] J.-C. Gao, L.-Y. Qiao, and R.-L. Xin, "Corrosion and bone response of magnesium implants after surface modification by heat-self-assembled monolayer," Frontiers of Materials Science in China, vol. 4, no. 2, pp. 120-125, 2010.

[120] J. Wang, J. Tang, P. Zhang et al., "Surface modification of magnesium alloys developed for bioabsorbable orthopedic implants: a general review," Journal of Biomedical Materials Research Part B: Applied Biomaterials, vol. 100, no. 6, pp. 1691-1701, 2012.

[121] J. E. Gray and B. Luan, "ChemInform Abstract: Protective Coatings on Magnesium and Its Alloys - A Critical Review," ChemInform, vol. 33, no. 26, pp. no-no, 2002.

[122] M. C. Turhan, R. Lynch, M. S. Killian, and S. Virtanen, "Effect of acidic etching and fluoride treatment on corrosion performance in Mg alloy AZ91D (MgAlZn)," Electrochimica Acta, vol. 55, no. 1, pp. 250-257, 2009.

[123] M. Assadian, M. H. Idris, M. M. Taheri, M. Rezazadeh Shirdar, and D. Almasi, "Effects of Alkaline Treatment on Corrosion Behavior of Biodegradable Magnesium," Advanced Materials Research, vol. 1125, pp. 441-444, 2015.

[124] L. Li, J. Gao, and Y. Wang, "Evaluation of cyto-toxicity and corrosion behavior of alkali-heat-treated magnesium in simulated body fluid," Surface and Coatings Technology, vol. 185, no. 1, pp. 92-98, 2004.

[125] F. Witte, "The history of biodegradable magnesium implants: a review," Acta Biomaterialia, vol. 6, no. 5, pp. 1680-1692, 2010.

[126] T. Berglundh, I. Abrahamsson, J.-P. Albouy, and J. Lindhe, "Bone healing at implants with a fluoride-modified surface: an experimental study in dogs," Clinical Oral Implants Research, vol. 18, no. 2, pp. 147-152, 2007.

[127] G. Lei, K. Liu, S. Zhang et al., "Cytotoxicity of AZ31B magnesium alloy covering with magnesium oxide," Rare Metal Materials and Engineering, vol. 37, no. 6, pp. 1027-1031, 2008.

[128] T. S. N. Sankara Narayanan, I. S. Park, and M. H. Lee, "Strategies to improve the corrosion resistance of microarc oxidation (MAO) coated magnesium alloys for degradable implants: Prospects and challenges," Progress in Materials Science, vol. 60, no. 1, pp. 1-71, 2014.

[129] S. N. Tsn, I. S. Park, and H. L. Min, "Surface modification of magnesium and its alloys for biomedical applications: opportunities and challenges," in Surface Modification of Magnesium and its Alloys for Biomedical Applications, pp. 29-87, 2015.

[130] R. Narayanan, S. K. Seshadri, T. Y. Kwon, and K. H. Kim, "Calcium phosphate-based coatings on titanium and its alloys," Journal of Biomedical Materials Research Part B: Applied Biomaterials, vol. 85, no. 1, pp. 279-299, 2007.

[131] B. Wang, P. Huang, C. Ou, K. Li, B. Yan, and W. Lu, "In vitro corrosion and cytocompatibility of ZK60 magnesium alloy coated with hydroxyapatite by a simple chemical conversion process for orthopedic applications," International Journal of Molecular Sciences, vol. 14, no. 12, pp. 23614-23628, 2013.

[132] A. E. Coy, F. Viejo, F. J. Garcia-Garcia, Z. Liu, P. Skeldon, and G. E. Thompson, "Effect of excimer laser surface melting on the microstructure and corrosion performance of the die cast AZ91D magnesium alloy," Corrosion Science, vol. 52, no. 2, pp. 387-397, 2010.

[133] L. F. Guo, T. M. Yue, and H. C. Man, "Excimer laser surface treatment of magnesium alloy WE43 for corrosion resistance improvement," Journal of Materials Science, vol. 40, no. 13, pp. 3531-3533, 2005.

[134] W. Khalfaoui, E. Valerio, J. E. Masse, and M. Autric, "Excimer laser treatment of ZE41 magnesium alloy for corrosion resistance and microhardness improvement," Optics and Lasers in Engineering, vol. 48, no. 9, pp. 926-931, 2010. 
[135] M. A. Melia, D. C. Florian, F. W. Steuer et al., "Investigation of critical processing parameters for laser surface processing of AZ31B-H24," Surface and Coatings Technology, vol. 325, pp. 157$165,2017$.

[136] A. C. W. Noorakma, H. Zuhailawati, V. Aishvarya, and B. K. Dhindaw, "Hydroxyapatite-coated magnesium-based biodegradable alloy: Cold spray deposition and simulated body fluid studies," Journal of Materials Engineering and Performance, vol. 22, no. 10, pp. 2997-3004, 2013.

[137] D. F. Williams, "On the mechanisms of biocompatibility," Biomaterials, vol. 29, no. 20, pp. 2941-2953, 2008.

[138] F. L. Nie, Y. F. Zheng, S. C. Wei, C. Hu, and G. Yang, "In vitro corrosion, cytotoxicity and hemocompatibility of bulk nanocrystalline pure iron," Biomedical Materials, vol. 5, no. 6, Article ID 065015, 2010.

[139] Y. Xin, T. Hu, and P. K. Chu, "In vitro studies of biomedical magnesium alloys in a simulated physiological environment: A review," Acta Biomaterialia, vol. 7, no. 4, pp. 1452-1459, 2011.

[140] X. Gu, Y. Zheng, Y. Cheng, S. Zhong, and T. Xi, "In vitro corrosion and biocompatibility of binary magnesium alloys," Biomaterials, vol. 30, no. 4, pp. 484-498, 2009.

[141] A. H. M. Sanchez, B. J. C. Luthringer, F. Feyerabend, and R. Willumeit, "Mg and Mg alloys: How comparable are in vitro and in vivo corrosion rates? A review," Acta Biomaterialia, vol. 13, pp. 16-31, 2015.

[142] D. Dziuba, A. Meyer-Lindenberg, J. M. Seitz, H. Waizy, N. Angrisani, and J. Reifenrath, "Long-term in vivo degradation behaviour and biocompatibility of the magnesium alloy ZEK100 for use as a biodegradable bone implant," Acta Biomaterialia, vol. 9, no. 10, pp. 8548-8560, 2013.

[143] E. L. Zhang, L. P. Xu, G. N. Yu et al., "In vivo evaluation of biodegradable magnesium alloy bone implant in the first 6 months implantation," Journal of Biomedical Materials Research Part A, vol. 90A, no. 3, pp. 882-893, 2009.

[144] Y. Li, Q. Li, S. Zhu et al., “The effect of strontium-substituted hydroxyapatite coating on implant fixation in ovariectomized rats," Biomaterials, vol. 31, no. 34, pp. 9006-9014, 2010.

[145] M. Waselau, V. F. Samii, S. E. Weisbrode, A. S. Litsky, and A. L. Bertone, "Effects of a magnesium adhesive cement on bone stability and healing following a metatarsal osteotomy in horses," American Journal of Veterinary Research, vol. 68, no. 4, pp. 370-378, 2007.

[146] C. Castellani, R. A. Lindtner, P. Hausbrandt et al., "Boneimplant interface strength and osseointegration: biodegradable magnesium alloy versus standard titanium control," Acta Biomaterialia, vol. 7, no. 1, pp. 432-440, 2011.

[147] U. Saran, S. G. Piperni, and S. Chatterjee, "Role of angiogenesis in bone repair," Archives of Biochemistry and Biophysics, vol. 561, pp. 109-117, 2014. 

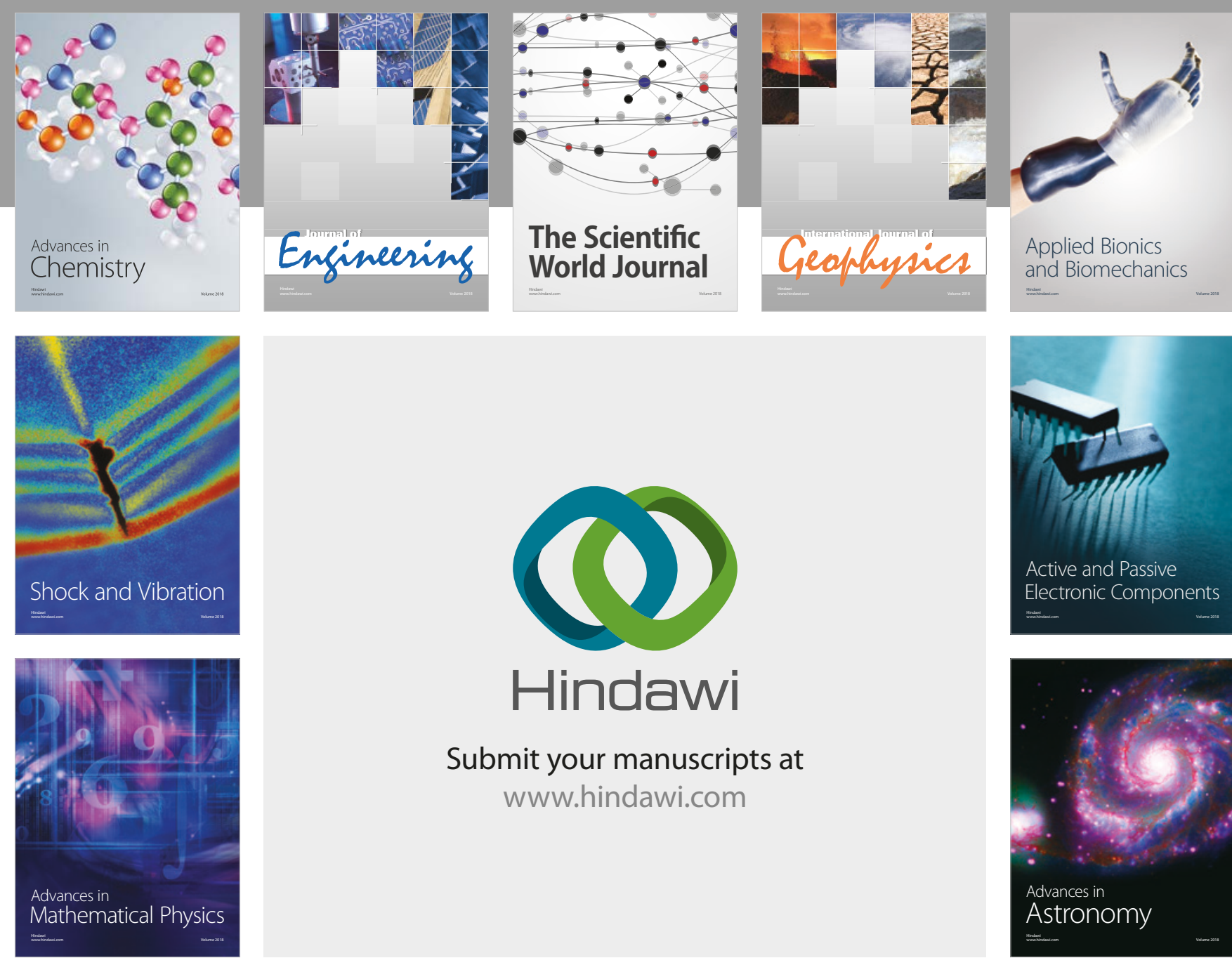

Submit your manuscripts at

www.hindawi.com

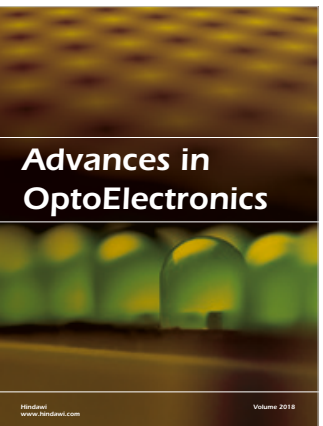

\section{Rotcting Machinery}
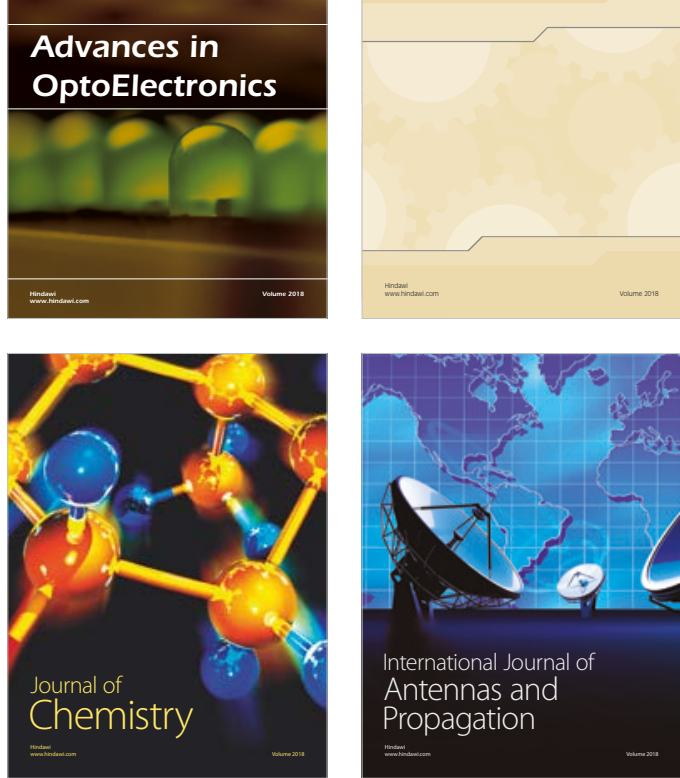

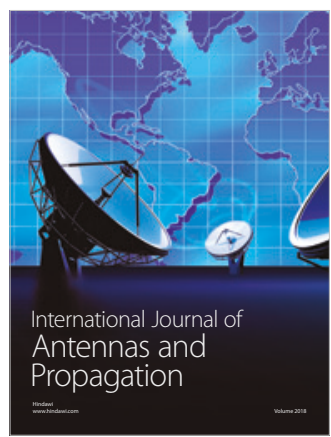

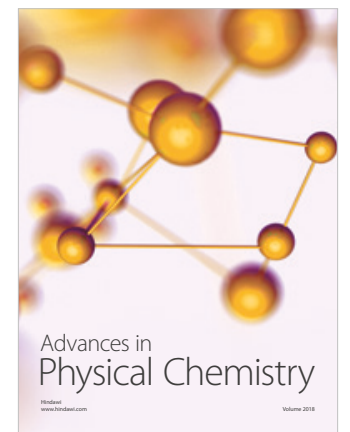

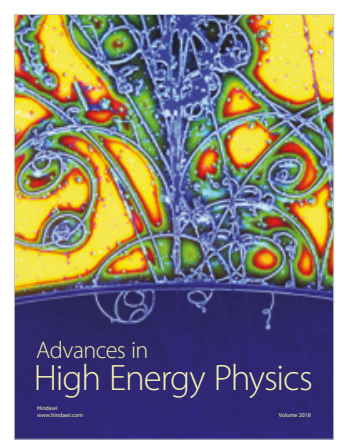

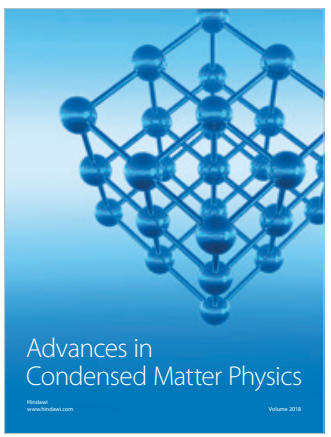

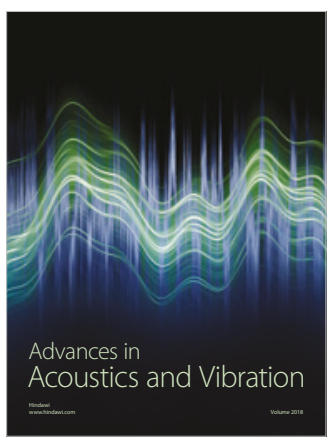

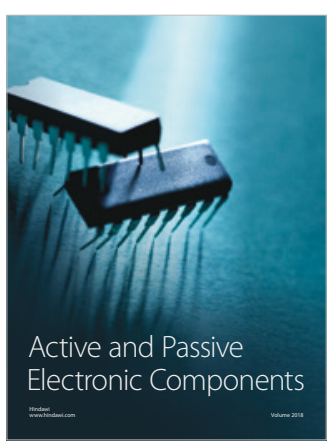
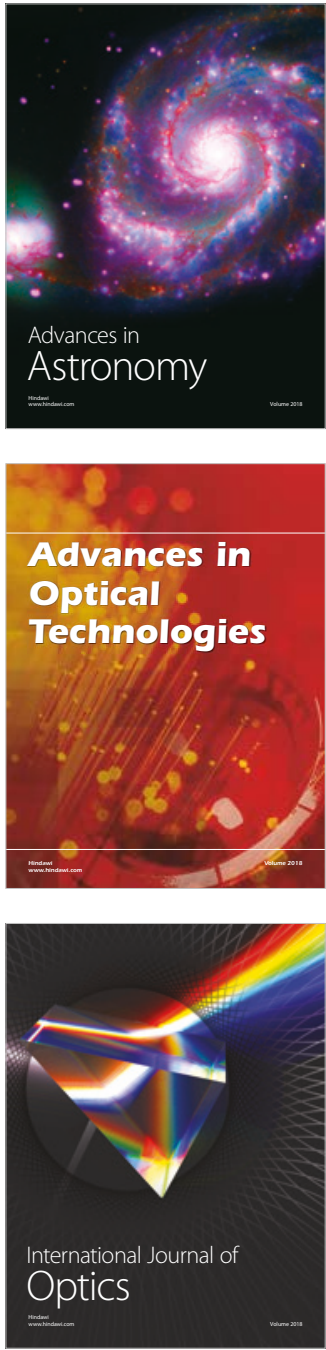